\title{
Plants growing in and on bodies in folklore*
}

\section{Plantas que crecen en y sobre los cuerpos en el folklore}

\author{
DAVIDE ERMACORA \\ (Università Ca’ Foscari Di Venezia) \\ davide.ermacora@gmail.com \\ ORCID: 0000-0002-6908-4500
}

\begin{abstract}
The aim of this paper is to provide evidence for three themes related to 'botanical bosom serpents', i.e. stories about plants growing in and on bodies. First, the sprouting of flowers from the body in medieval Christian tales, to be contrasted to 'bottom flowers' attested in Dutch profane paintings produced in the later Middle-Ages; second, the presence of botanical bosom serpent narratives in Japan; and, third, the topic of plants growing in, and on animals in oral traditions and works of natural history.
\end{abstract}

KeYwORDS: botanical bosom serpent, plants, flowers, parasites
RESUMEN. El objetivo de este ensayo es ofrecer más materiales e interpretaciones relacionados con el tópico de la botanical bosom serpent, es decir, con historias acerca de plantas que crecen en el interior o en la piel de los cuerpos. En primer lugar, analizo el tema del brote de flores sobre el cuerpo, que aparece en cuentos cristianos medievales, y que contrasto con las 'flores que nacen de los traseros' que aparecen en pinturas profanas de Holanda en la Edad Media y el Renacimiento; en segundo lugar, estudio la presencia de relatos acerca de plantas que nacen del cuerpo en Japón; y, en tercer lugar, me ocupo del tema de las plantas que crecen en y sobre los animales en diversas tradiciones orales y en obras de historia natural.

Palabras-Clave: botanical bosom serpent, plantas, flores, parásitos

\section{INTRODUCTION}

In a previous paper I conducted a comparative survey of folk traditions involving plants and other vegetable elements growing in and on the human body. As the term 'bosom serpent' is employed by folklorists for animals which (allegedly) dwell in the human body, I called these plant and vegetable traditions 'botanical bosom serpents' (henceforth BBS: see Ermacora, 2020). The aim of this paper is to provide additional evidence for three themes (closely or distantly) related to BBS: first, the sprouting of

* Unless otherwise stated, all translations are my own, all dates are Anno Domini (AD), and the references to folklore motifs are from Stith Thompson's Motif-Index of Folk-Literature (Thompson, 19551958). I am grateful to Alberto de Antoni, Tommaso Braccini, Jessica Hemming, Roberto Labanti, Andrea Marcon, Antone Minard, Costantino Nicolizas, José Manuel Pedrosa, Rodo Pfister, Biagio Santorelli, Stefan Schnieders and Simon Young for help in writing this paper. 
flowers from the body in medieval Christian tales, to be contrasted to 'bottom flowers' attested in Dutch profane paintings produced in the later Middle-Ages; second, the presence of BBS narratives in Japan; and, third, the topic of plants growing in and on animals in oral traditions and works of natural history. In all these cases we can say that, as Bradford McMullen put it, «The exaggeration is the ability of the seed to grow in something other than soil» (McMullen, 2015: 46).

Flowers SPROUTING FROM HUMANS: FROM CHRISTIAN DEVOTION TO THE GROTESQUE BODY

There is a famous medieval account of an illiterate but devoted French Benedictine monk, named Joscius, «transformed into a portable garden» (Hariot, 1906: 113). This account is to be found in the Dominican friar Vincent de Beauvais' widely read thirteenthcentury universal history Speculum historiale 8: 116. When Joscius died in his cell at the Abbey of St. Bertin in Saint-Omer, in 1163, five roses (flores rosarum) were found: one in his mouth, and one in each eye and each ear (Latin text of the Douai version in Atelier Vincent de Beauvais, 2015; see also Moser, 1977: col. 1097; Berlioz, Collomb, Polo de Beaulieu, 2001: 82; Thesaurus Exemplorum Medii Aevi, 2017). This is among the earliest attested versions of a cycle of pious medieval legends, likely of Cistercian monastic origin, called by Laurel Broughton «lily miracles». These are, Broughton assures us, probably «the largest single subgroup of miracles of the Virgin» (Broughton, 2005: 593; 2006: 287).

In lily miracles, attested from the second half of the twelfth century onwards, beautiful flowers such as roses or lilies represent Hail Mary or other Marian prayers / hymns. They bloom out of the heads of those who practice extraordinary devotion to the Virgin. In other funerary variants, as in Vincent de Beauvais, flowers are found in the mouth of dead devotees or are even discovered growing out of innocent murder victims (killed, for instance, by Jews) when their graves are opened: motifs E631.1.1 Lily from grave; E631.1.2 Rose from grave (Blümml, 1906; Gougaud, 1915; Boyd, 1957; Graffius, 1961; Moser, 1977; Broughton, 2005: 593-594; Lavezzo, 2016: 111-113 and 131-132; see exempla no. 427 Ave Maria on Lily; 437 Ave Maria, thief says; 2094 Flower Grows Out of Corpse's Mouth in Tubach, 1969: 38-39 and 168)1.

In their search for «everything that is surprising and odd» (Pimentel, 2009: 104), several Renaissance authors briefly compared Vincent's five-rose man to heterogeneous accounts where BBS bring sickness and physical discomfort (Latin texts in Nieremberg, 1635: 31-32; Borel, 1656: 18; Bernitz, 1671: 96-97). The problem with this is that the flowers showing up in lily miracles are not hostile / connected to disease. Rather, they are a religious symbol with positive moral connotations - something very close to a literary or artistic

\footnotetext{
${ }^{1}$ The flower which spontaneously grows from or on a corpse buried in the ground is an extremely widespread idea, and thus the funerary lily miracles may connect to international motifs such as A2611 Plants from body of slain person or animal; A2611.0.1 Plants from grave of dead person or animal; E631 Reincarnation in plant [tree] growing from grave (Propp, 1975). The relationship between this folklore corpus and medieval lily miracles awaits, however, further investigation. One could usefully mention the English post-medieval ballad Barbara Allen, in which a rose and a briar grows from the grave of unfortunate dead lovers and form a knot together. The lovers are, thus, united in death: ATU 970 The Twining Branches, employing motif E631.0.1 Twining branches grow from graves of lovers (Lang, 1980; Goldberg, 1997: 176; Uther, 2011: 607). See Mañero Lozano (2020) for the Spanish tale, attested from the seventeenth century to the present day, about a walker who discovers a flower which had sprouted on a skull or through its orbits. This often triggers a poetic reflection on death.
} 
metaphor. These tales have a clear didactic purpose and most often symbolize the Virgin and the doctrine of Incarnation (Moser, 1977; Broughton, 2005: 593-594; 2006: 293-294)2.

The medieval lily miracles, with their mythical «vegetable manifestations» (Laurentin, Sbalchiero, 2007: 582), were taken seriously in the context of late medieval popular Marian devotion. It is perhaps worth contrasting these 'Christian flowers', however, to some 'bottom flowers' sprouting from the human anus. This is a rare grotesque iconographic theme which seems to have developed in the Southern Netherlands at the end of the Middle Ages. Two pieces of evidence are known (already compared by De Bruyn, 2011). The first is a secondary detail from the 1490-1500 (?) triptych Garden of Earthly Delights by the Dutch painter Hieronymus Bosch (ca. 1450-1516): two flowers protrude from, or have been inserted into the anus of a naked male figure crouched on the grass (Figure 1). A reference to sodomy? (Rooth, 1992: 37; De Bruyn, 2011)

The second piece of evidence is the internal side of a panel from an anonymous profane Flemish diptych, painted ca. 1520: two thistles point towards the bare buttocks of a jester. The caption in Middle Dutch reads: «Don't be angry with me, because I warned you well» (translation in Heyworth, 2009: 966) - a message alluding to the other panel verse in which the same jester had, before, told the spectator to leave the panel closed (Figure 2) (see Weising, 2008: 335; Heyworth, 2009: 966-967; Alberti, Bodart, 2018: 15-17). The two thistles associated with the buttocks were, one understands, a source of pained amusement for the observers. They have remained puzzling to art historians (Ganz, 2010: 64) and none have evoked the wider imagery of flowers growing in or on bodies. The most compelling reading is that of Eric De Bruyn. He employed Dutch dialectological / literary materials and proposed that the flowers, in Bosch and the diptych, referenced

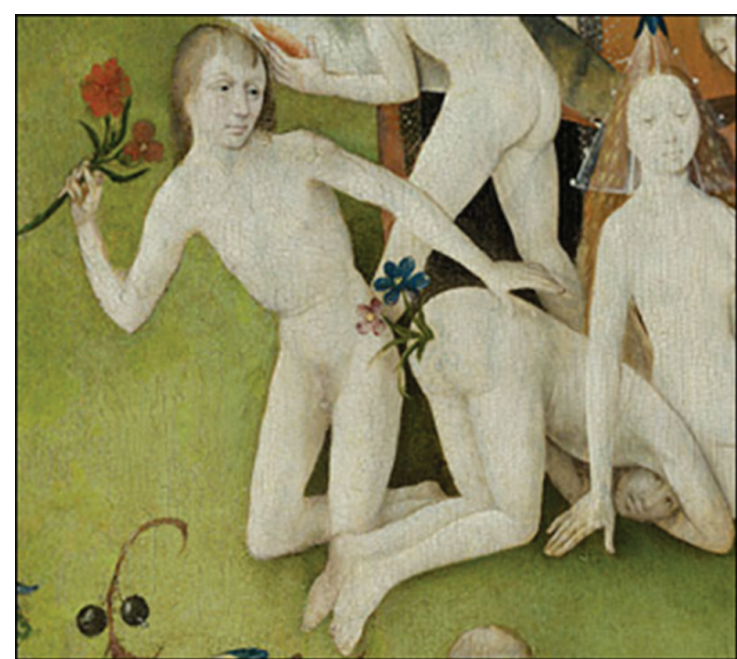

Figure 1

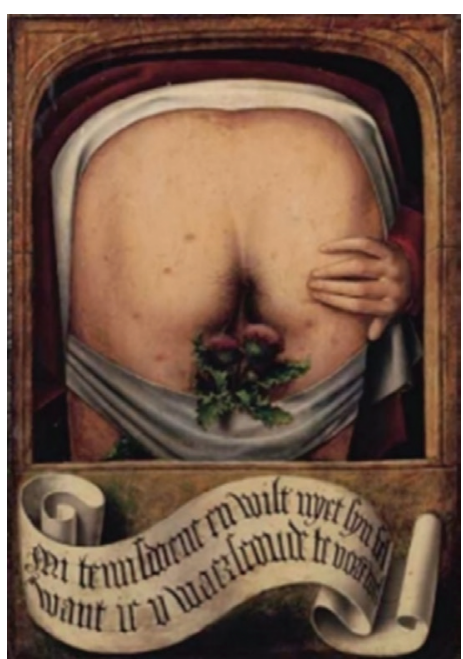

Figure 2

\footnotetext{
${ }^{2}$ As for roses as BBS, there is a seventeenth-century case mentioned by the German physician Alhard Hermann Kummen. In 1665, he personally cured a German nobleman who, while in Amsterdam, had fallen ill because of a love potion. Kummen made the patient vomit several fresh rose petals (rosarum folia recentia adhuc) with the help of an emetic; when the man threw out the last petal, he suddenly hated the woman whom he had previously loved. Kummen's assumption, one understands, was that the rose petals had been generated in the man's stomach due to bewitchment, not that they were part of a potion that he had inadvertently swallowed (Latin text in Kummen, 1672: 179, who cited the story in relation to other BBS reports; see also Schurig, 1725: 439-440).
} 
bowel movements and excrement. These latter, in the early modern Netherlands, were occasionally called 'flowers' and / or compared, in a typical humorous or tabooed reversal process, to flowers (De Bruyn, 2011).

\section{BOTANICAL BOSOM SERPENTS IN JAPAN}

In everyday life one can easily gulp down seeds while eating fruit. Between the eighteenth and the nineteenth century, English-speaking authors regularly cautioned people, and in particular children, that swallowed fruit seeds could lead to fearful obstructions of the airways, stomach, etc. (see e.g. Baddam, 1739; C. H., 1759; Anonymous, 1764; Alcott, 1838: 245-252). From the not always carefully defined 'bad consequences' of fruit swallowing we have, indeed, the widespread belief that cherry-stones and seeds can germinate inside the stomach and elsewhere in the body - a motif which has a long history, and which can be found in many parts of Europe (Ermacora, 2020). One can usefully mention a sixteenth-century German anecdote about a man who has a pomegranate tree starting to grow out of his head: he had swallowed some seeds.

The story was included in the 1594 German comic play Von Vincentio Ladislao, composed by Duke Henry Julius of Brunswick-Lüneburg (1564-1613). The protagonist of the comedy, the braggart and man at arms Vincentius Ladislaus, a precursor of the Baron Münchhausen (see e.g. Pfeiffer, 1849: 187; Holland, 1855: 897-903; Garvin, 1923: 37-38; Eyssen, Storch, 1983: 80), is invited to dine at the court of Duke Silvester. While at table, Vincentius narrates some wondrous hunting narratives (lucky shots, etc.) in a dialogue with Johan Bouset, the court jester who is making fun of him. When Vincentius sees the duke eating an apple and swallowing its seeds, he says: "In truth, my Lord, it is not good that your Grace eats the [apple] seeds. We have met a man who had also eaten many pomegranate seeds (GranatEpffel Körner), and eventually a large pomegranate plant grew from his mouth, eyes, ears and from the nostrils». This is not just a matter of telling a good tale: Vincentius adds a personal touch. «What a beautiful pomegranate [tree] he kept, we saw it and we ate [fruits from it] ourselves» (German text in BraunschweigWolfenbüttel, 1967: 78)3.

It should be remembered that, in the very same section of the comedy, just before this story, Vincentius is involved in an exchange of hunting tales. Indeed, a few commentators of Henry Julius' work have briefly evoked the famous Münchhausian hunting narrative, which I will examine below, of the deer with a cherry tree on its head: tale-type ATU 1889C Fruit Tree Grows from Head [or Back] of Deer Shot with Fruit Pits, also given as motif X1130.2 Fruit tree grows from head [or back] of deer shot with pit or pits of fruit by hunter who had no regular bullets (Uther, 2011: 474; see Raspe, 1948: 12). In both Münchhausen and the Ladislaus' play, these commentators seem to have thought, we have tall tales with BBS at work; but there is no hunting scenario in the pomegranate seeds anecdote, and the BBS grows on a man not on a deer there (pace Müller-Fraureuth, 1881: 75; Burger, 1968: 76).

What is interesting is that a folklore motif similar to the 'pomegranate-man' also shows up in distant Japan - a motif which joins BBS together with negative traits such as greediness / gluttony / avarice. A well-known surreal nineteenth-century traditional story

\footnotetext{
${ }^{3}$ That analogous (fanciful) tales were current in Germany in the same period, we know from chemist and physician Andreas Libavius (ca. 1550-1616). In a learned discussion about BBS medical reports, he notes: «the one who has collected the fruits of a tree born inside a man - such as is told of in the ancient tales which circulate among the young — has not yet been found» (Latin text in Libavius, 1601: 357).
} 
is the rakugo 落語 tale-type Atama yama 頭山, classed as tale-type no. 383 A Persimmon Tree on the Forehead or 1886 A Persimmon Tree on a Man's Head in, respectively, Keigo Seki's and Hiroko Ikeda's index of Japanese folk tales (Seki, 1966: 181-182; Ikeda, 1971: 276). There, a cherry grows upon a stingy man's head after he swallows some cherry stones which had fallen upon the road: he is so stingy that he is unable to spit out the seeds but gulps them down. «When, in spring, singing and laughing people gather under the tree to view its blossoms, [the man] becomes furious and pulls [the cherry tree] out [from his head]. In the remaining hole, rainwater forms a pond. Again joyous people crowd around». The tale ends badly: in rage and despair, the man «jumps into the pond which was on top of his own head and drowns» (Miyoko, Heinz, 1990: 110).

It is commonly accepted that a handful of Western stories spread into the rakugo repertoire at the beginning of the Meiji period, that is, during the second half of the nineteenth century when Japan came into sustained contact with the West (Oda, 1989: 47; Miyoko, Heinz, 1990: 188). In their discussion of the grotesque Atama yama tale where the frustrations of a miser are depicted, Morioka Heinz and Sasaki Miyoko recalled, too, the cherry-pits and the deer in Münchhausen, and excluded an earlier transmigration of BBS folklore motifs from West to East (Miyoko, Heinz, 1990: 188). I can add that only one (early twentieth-century?) variant of ATU 1889 C seems to be known in Japan (Mayer, 1986: 218), something that renders even more unlikely the influence of the Münchhausian hunting tale on the Atama yama tale-type.

Folklore transmission patterns across cultures are notoriously hard to trace. In the light of Vincentius' sixteenth-century 'pomegranate-man' and the long-attested (and, indeed, pervasive) BBS folklore which I have investigated in Ermacora (2020), one should be careful, however, in altogether dismissing a hypothetical earlier folklore contact between the West and Japan. The opposite explanation is parallel development. Miyoko and Heinz stressed the role played by traditional rakugo storytellers performing comic monologues on stage. They traced the cherry-tale's basic pattern back to the fourteenth century, in a Japanese story contained in Yoshida Kenkō's 兼好 Buddhist collection of short essays Tsurezuregusa 徒然草, ca. 1330-1332, where «the tree does not grow yet upon a man's head but in his garden» (Miyoko, Heinz, 1990: 110 and 198; see also, independently, Muramatsu, 1988: 35).

Miyoko and Heinz also found seventeenth- and eighteenth-century literary versions of the Atama yama with «trees» growing from the shoulder of a Buddhist monk; and a «plum tree» coming out of the head of a pious devotee of Tenjin. Both, it seems, were so deep in their meditations that they did not notice the growth of the plants ${ }^{4}$. Finally, Miyoko and Heinz identified a 1781 «head tree» transformed into a blooming cherry tree growing on the head of a row-house tenant. «The landlord pulled the tree out because of the noise caused by the people who came to view the blossoms. The resulting pond attracted people for fishing and fireworks». Again, «irritated by the noise, the landlord suggested that the unlucky tenant leave the house or drown himself in the pond upon his own head» (Miyoko, Heinz, 1981: 432 and 453-454; 1990: 110, 120, 197-199 and 302).

Details vary and the Atama yama tale-type does not always imply, apparently, a central character (such as a miser) suffering for his character flaws. An even earlier text,

\footnotetext{
${ }^{4}$ It is perhaps worth making a parallel here with the Virgin's lily discussed above. In both cases we would have, on the one hand, a plant / flower growing out of the body as a reward for what might be called 'piety'; on the other, a plant / flower resulting from the "repetition of orthodox forms of worship" [Authors" italics] (Blurton, Johnson, 2015: 152; 2017: 179): prayers in Europe, meditation in Japan.
} 
1773, has a man who «ate too many cherries and had a dream that his head was so big a

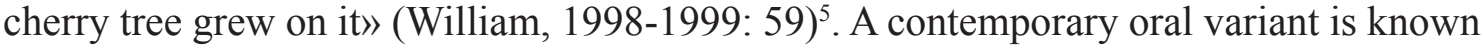
in which the seed of an orange first sprouts in the man's stomach and then grows out of his head (Mayer, 1986: 208 and 218). Other humorous Japanese oral renditions of the Atama yama have happy endings, such as those in which «A ripe persimmon falls and squashes [sic] on a man's head. A seed sticks [to] his forehead and takes root. Soon it is full[y]grown and bears many fruits. The man peddles them at a good profit». His envious friends can feature as antagonists, and so in some tales they cut down the persimmon tree: this triggers a chain of events that ultimately leads the man to jump into the pond on his head and drown himself — by now a familiar detail (Ikeda, 1971: 276; see also Seki, 1966: 181182; Miyoko, Heinz, 1990: 302). It is hoped that folklorists will be able to bring us more examples of BBS from Japan.

\section{Plants gROWING IN AND ON ANIMALS: TALl TALES}

Wondrous accounts of plants growing in or on animals are, perhaps, not as plentiful as those in which people are the hosts (Stalpart van der Wiel, 1758: 92-93; Ermacora, 2020). A survey will be provided here. In Southern California, in the early 1870s, there was much sheep rearing (Bilanchone, 2006: 379); this helps give some context, perhaps, to a short note from the Sacramento Daily Union which was published, in 1872, under the humorous title «Peripatetic pastures». It is said there that several sheep from Patton's ranch were not sheared the previous fall, hence their fleece had grown long. «During the fall [the fleeces] got very dirty, and probably grass and other seed fell into it. At all events, since rain commenced to fall, grass, with blades say two inches long, is growing luxuriantly out of the wool». The sheep, thus, currently «travel about carrying their pastures upon their backs. Any grass which the sheep cannot reach itself a friend is allowed to nibble, and he or she reciprocates». The anonymous reporter concludes, wisely, that «We haven't seen the sheep our-selves» (Anonymous, 1872a).

Is this a tall tale which found its way into the local press? The sheep report circulated widely in America and Britain: some newspapers explicitly classed it as a «"tall" story» (Anonymous, 1872b); gave it different humorous titles such as «A walking pasture» (Anonymous, 1872c); or subtly made fun of the piece labelling it «a plain, simple statement, so evidently accurate and at the same time so instructive» (Alden, 1872: 796). It might be worth remembering here Shrek and Chris, two 'hermit' sheep rescued, respectively, in 2004 in Bendigo, New Zealand, and 2015 in Canberra, Australia. Both sheep had lived in the wild for ca. six years and, after having been caught, Shrek had 27 and Chris had 41 kilograms of overgrown wool cut from their body: they had no vegetation growing on them when they were found.

The Baron Münchhausen stories, by the German writer Rudolf Erich Raspe (17361794), appeared in German in 1781, though they only became famous in 1785 after being translated into English by Raspe. One of the most popular tall tales there (already attested in the 1781 redaction: Müller, 1988: XXIII; Miyoko, Heinz, 1990: 198), has, as I said above, a fully-grown plant which appears inside the body of a deer (Raspe, 1948: 12). This tale spread orally all around the world helped by the remarkable written circulation

\footnotetext{
${ }^{5}$ Is the dream element here, perhaps, a re-interpretation of more 'literal' parallel stories where the protagonist, while sleeping, has a persimmon seed thrown onto his forehead which subsequently grows and bears fruit? An example is summarized in Seki (1966: 181).
} 
of Raspe's oeuvre. For example, many versions of wonderful hunts and trees growing out of animals, which «reinforces the absurdity of the hero's idea, making the shot lifebringing instead of life-ending» (McMullen, 2015: 46-47), were collected in the Americas (including Canada and Latin America). These were places in which hunting played (and still, in some cases, plays) a major part in local life (Anderson-Green, 1983: 69).

In North America, in particular, it seems that ATU 1889C has been reported far more often than in any other country, making it a true classic of humorous storytelling which «show how hunters can be creative with their ammunition» (McMullen, 2015: 56; see Walton, 1966: 237; Bethke, 1981: 53; Anderson-Green, 1983: 70). Of course, the type of seed, the animal (deer / stag, mule, horse, hare, alligator, bull, etc.) and the point where the animal gets shot vary. The key element is the animal found in a changed state - a tree has grown on it (cf. Figures 3 and 4) - after a 'preliminary' interaction with a hunter who had previously shot the animal with seeds ${ }^{6}$ (Blair, 1993; Uther, 2011: 474; 2015: 533, see also Bender, Vermorel, 1890: 184 who briefly considered Münchhausen as a counterpart to French «ridiculous fables of vines grafted on bramble, blackcurrant, quince, oak, etc.»).
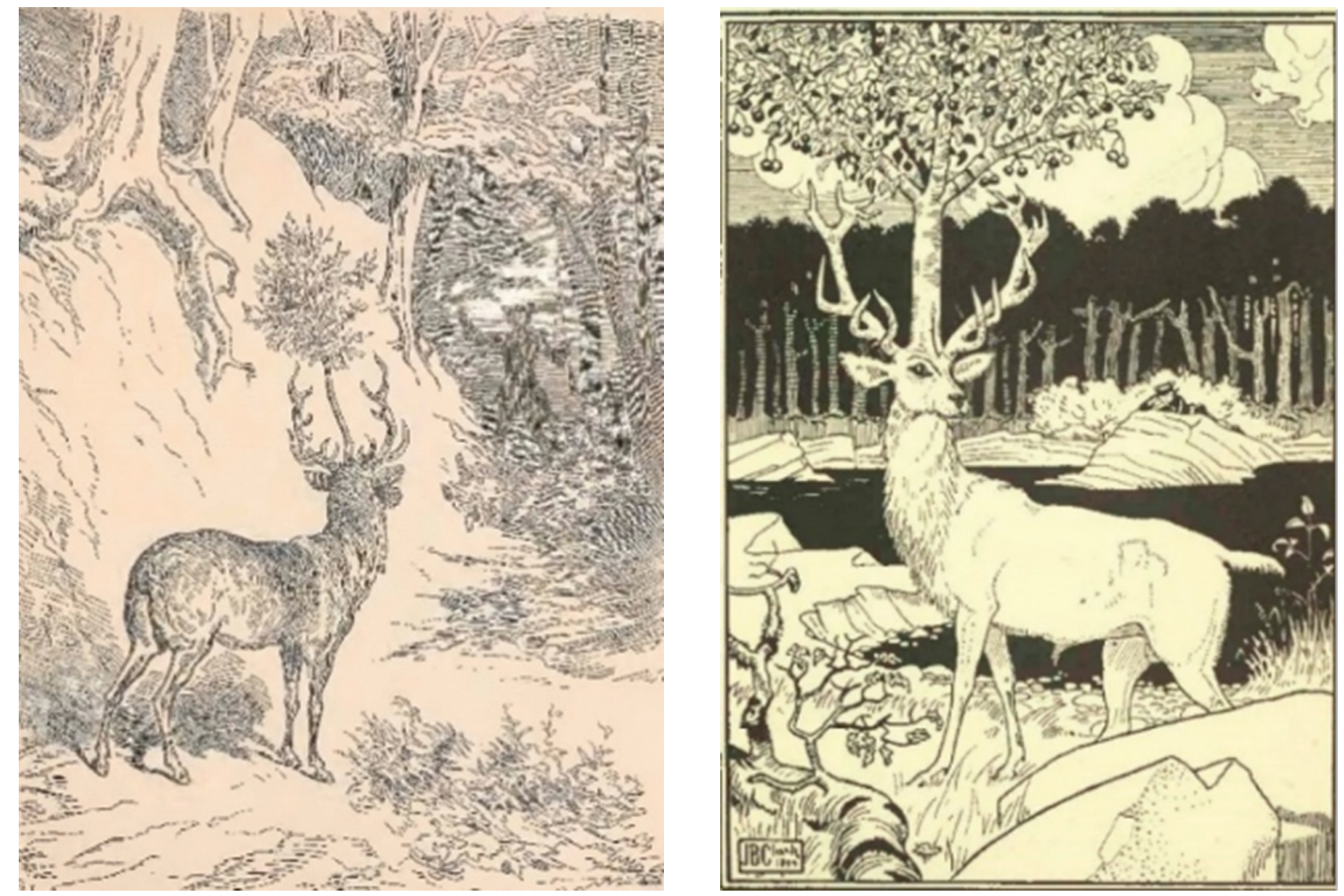

Figures 3 and 4: the cherry-deer encountered by the Baron Münchhausen. From, respectively, Raspe 1867: $23 ; 1895: 23$.

${ }^{6}$ This would bring ATU $1889 \mathrm{C}$ somehow close to those old wonderful stories where a hunter catches an animal, attaches something to the animal, and where the animal is captured by someone else many years later. The hunter may or not be a famous historical character, and the animal may or not be noted for his (alleged) longevity. There are tales involving stags / deer (the most famous being the medieval legend of Caesar's deer); tortoises (people carve messages on them; sometimes this is a result of forgery); fishes (plaques attached in silver) (see e.g. Plumley, 1921; Latham, Schlauch, 1969; Barth, 1979). 
Scholars have long wondered about the origins, influences, and transmission behind some Münchhausen tales (see e.g. Ellisen, 1849; Holland, 1855: 897-903; MüllerFraureuth, 1881, and Ziolkowski, 2007: 77-79; Uther, 2011: 476 for ATU 1889g Man Swallowed by Fish). So was the Baron Münchhausen, as Miyoko and Heinz suggested, «the first European to witness with his own eyes a tree growing from the head of a living being»? (Miyoko, Heinz, 1990: 197). This is an interesting question. The Münchhausian cherry-deer, for sure, is hardly based on the deer-like creature (a reindeer?) from Julius Caesar's first-century AD Commentarii de bello gallico 6: 26 (as proposed by Blair, 1993: 64; Latin text and translation in Caesar, 1917: 350-353); nor is the cherry-deer derived from the remarkable one-horned stag described in the Welsh tale Peredur, included in the thirteenth-century Mabinogion collection (as proposed by Hutchinson, 1864; Seccombe, 1895: XXVII; translation in Davies, 2007: 100-101). There are no hunts and no BBS show up there.

The same can be said for Saint Hubert and his old legend, in which a stag appears with a cross between its antlers: ATU 938 Placidas (the parallel was, however, endorsed by Loomis, 1945: 126; Thomas, 1977: 208; 1999: col. 1011; Goerge, 1993: col. 422; see Uther, 2011: 580-581). In ATU 938 there are no BBS and we are in a situation permeated by religion there, though it shares with ATU 1889C the element of the wondrous deer / stag. This is enough, in my opinion, to dismiss claims such as "The [Münchhausian] tale also exists as a saint's legend» (Thomas, 1977: 208) ${ }^{7}$. One will search in vain for Münchhausen cherry-tree deer in pre-Christian works or Christian hagiographic texts ${ }^{8}$. The cherry-tree-deer anecdote belongs, instead, to a complex of well attested tall tales about hunting and fishing, featuring BBS, which were certainly current in Germany, and elsewhere in Europe, during early modern times. This was first noted long ago.

Robert Southey, in 1808, was able to compare Münchhausen's tale to a variant of ATU 1889 C contained in a humorous Portuguese periodical published in 1730, stressing their resemblance. «In some letters coming from Alcalede it is said that an inhabitant of that city went, one day, this last week, to hunt». The man shot a deer (viado: not a «wild boar», pace Southey, 1808: 223) with a peach stone he found on the ground because he had finished all his lead balls: he «hit it in the lumbar part of its trunk. Since it was a peach seed and not a real bullet, the man only wounded the animal. The deer therefore managed to escape». The next day (a magical element) the man returned to the place and saw «a tree that was moving among [other trees] and was trying to escape from there with some haste». The man, "frightened but wondering at the same time», went to see it and realized that it was the deer with a peach-tree growing out of his back. "This story became so famous (lit. nova 'new') that it caused wonder in all those who heard it. At that time, numerous hunting trips were organized in the hope of finding the tree, cutting it down and

\footnotetext{
${ }^{7}$ After all, Hubert's stag and the cherry-deer were already linked - and kept separate - by Baron Münchhausen himself, who was made, by Raspe, to ridicule the Christian legend wondering whether «some passionate holy sportsman, or sporting abbot or bishop, may have [equally] shot, planted, and fixed the cross between the antlers of St. Hubert's stag» (Raspe, 1948: 13; see also Morioka, Sasaki, 1990: 197).

${ }^{8}$ Or even earlier iconography. A distinctive artistic motif of the Iron Age Alpine situla art has plantlike elements such as tendrils / twigs / flowers («lotus» for Goodyear, 1891: 252) 'issuing' from the mouth of sphinxes and herbivorous animals depicted in procession: deer (mostly), bovine, mountain goat, etc. (Ducati, 1923: 76; see De Navarro, 1972: 261 and 281; Frey, 2011: 303-303 for early Celtic parallels). There is no need to see BBS at work here: we may just be dealing with a stylized (ornamental?) representation of animals which hold some plants in their mouth, and/or are chewing them.
} 
taking it to Court; the lucky man capable of managing this would earn a lot of money by simply showing it» (Távora, da Costa, 1730).

Without claiming that Raspe relied on the Portuguese source, admittedly an obscure one, Southey wisely concluded that «it is probable that the Portugueze $[\mathrm{sic}]$ and English writers both have had recourse to the same store-house of fable» (Southey, 1808: 223; see also Shore, 1867: XIV; Anonymous, 1870: 1741). Then, Carl Müller-Fraureuth pointed out, in 1881, that another pre-Münchhausen version of ATU $1889 \mathrm{C}$ is contained in Der lustige Teutsche, a collection of amusing and licentious anecdotes published in 1729 by Johann Paul Waltmann (a.k.a. Gottfried Rudolf von Sinnersberg). In respect of Münchhausen, the main difference is that plum kernels instead of cherry-stones are used as ammunition there, it is claimed by a braggart (Aufschneider), to shoot a deer (German text in Waltmann, 1729: 286; see Müller-Fraureuth, 1881: 75, 81 and 140, taken up in Rose, 1931: 120; Curts, 1948: 101).

It appears now that Waltmann simply took up - directly, or through an intermediate source - the following anecdote originally given, with minimal variations, by poet and writer Georg Philipp Harsdörffer (1607-1658). It was inserted in a miscellaneous section «on funny and clever actions» (there is a play on listige and lustige) in the 1660 posthumous extended edition of his collection of tales Der grosse Schau-Platz Lust- und Lehrreicher Geschichte. Here the protagonist is an adventurer (Abenteurer), and he shoots one (not many) seed bullets. «An adventurer said that, lacking a lead bullet, he had loaded the barrel with a plum kernel and then shot a deer on his forehead». After a few years, «the deer had encountered him again, and carried a plum tree between the horns which had grown on [the animal] forehead from that kernel» (German text in Harsdörffer, 1660: 370).

Finally, commenting on Münchhausen, it was discovered in 1870 that an even earlier Spanish variant of ATU 1889C, "with slight variations about a wild boar» (Anonymous, 1870: 1742), can be found in the 1525-1529 Crónica burlesca 2, by the court jester Don Francés de Zúñiga (1480-1532), a work which he had written to amuse his master Charles V (see also, independently, Grisebach, 1890: XXXIV; Chevalier, 1999: 68 and 221; Hernández, 2002: 115 and 324). To this I can add $^{9}$ a sixteenth-century (1579?) fishing story concerning a bizarre pike with a brush growing on it, from the French collection of tall tales La nouvelle fabrique des excellents traits de verité 82, by Cistercian monk Philippe le Picard (ca. 1531-1581). This is a work full of wondrous hunting and fishing stories (Schenda, 1958: 53; Thomas, 1977: 61-63). Here both texts follow on, first de Zúñiga, then Philippe:

The King left this place for a place called Ampudia, and there came upon don Pedro Manrique, Marquis of Aguilar, who told him: «Sir, I am a native of Spain, and those of the lineage where I come have always been loyal to the royal crown, more loyal than anybody. [...] They call me by the nickname Tocino [lit. Bacon, i.e. 'pork eater, Christian'], and I look like it. I own a mountain in Aguilar where Your Highness will kill many boars». The King asked for a description of the mountain and the Marquis told him: «Sir, I killed a very large boar the other day and I found between its two shoulders an oak tree, two

\footnotetext{
${ }^{9}$ Several authors, quoting each other, pointed out that ATU $1889 \mathrm{C}$ can be found in pre-Münchhausen compilations of facetiae such as the third book (1665) of Johann Peter Lange's Deliciae academicae (16631665), under the heading «Ridiculous lies for festive occasions» (Latin text in Lange, 1665: 121-159; see e.g. Anonymous, 1867: 1742; Seccombe, 1895: XXVII; Rose, 1931: 120; Curts, 1948: 101). There are, however, no references to ATU 1889C in Lange's work but a few parallels for Münchhausen's wonderful hunts and lucky shots (as was already pointed out by Holland, 1855: 897-903).
} 
arms long [ca. $3.5 \mathrm{mt}] \gg$. The King marveled at what the Marquis said, and commented: «Marquis, it sounds like a lie, how could this be true?» And [the Marquis], half laughing, answered: «Sir, three years ago a servant of mine while walking in that mountain gave the boar a spear blow, and it was the time of acorns, and the boar rolled over on the ground and got an acorn in the wound, and with the earth that entered and its body heat this oak grew upon it». (Spanish text in Hernández, 2002: 324, relying on Zúñiga, 1981: 70-71; see also Zúñiga, 1989: 68-69 for an edition based on a different manuscript)

Where they found an otter. Before the fish pond at Bray [= the French Pays de Bray region] was turned into a field, they found and caught with nets and other instruments a pike of the most horrible, frightening, incomprehensible, admirable, marvellous and invaluable length $[\ldots]$ seen since the Flood. Its head was bigger than an angler fish's and on it there was a bush or heap of grass and moss which, with time, had grown roots and pushed up; in that bush they found an otter, a master otter which had hidden in it for fear of fishermen, and that had them all amazed. It was caught and seized by the neck and made to give account of all the fish it had eaten without salt. The tyrant, pursued to his demise, / Often brings sorrow where he hides. (French text in Alcripe, 1983: 155, translation in Thomas, 1977: 132-133)

Indeed, the «traditional lie of the hunter who claims to have killed a boar on whose back an oak of reasonable size has grown», is a fine example of tall hunting tales, one of the best documented narrative genres of the Spanish Golden Age (Chevalier, 1999: 68-69 and 221). Oral narratives belonging to ATU 1889C continue to be told today in Aragon, in Catalonia and elsewhere in Spain (see e.g. Sales, 2002: 439-440; Sanz, 2013: 107-109); while narrative parallels closer to de Zúñiga's can be found abroad, such as the hunting tale from Virginia, USA, in which an acorn lodges in a sore on horse's back and an oak grows there (Baughman, 1966: 469-470).

Embedded in most collected variants of ATU 1889C there is a well-known dramatic device of storytelling, what has been called, in reference to the biography of the Appalachian humourist Harden Taliaferro (1811-1875), the «essential structural element of the tall-tale tradition, that is, the claim of the narrator to have experienced the adventure first-hand» (Anderson-Green, 1983: 70; see also Craig, 1987 for ATU 1889C and Taliaferro). Interestingly, this appears both in de Zúñiga and in the Münchhausian story, though through someone else's mouth: that is, the tales are told entirely by the tall tale hero rather than by Raspe or de Zúñiga (see Hunter 1992 for a survey of the categories of narrative voice in the tall tale genre). The liar protagonist of the Spanish hunting adventure is a historical aristocratic figure, the Marquis of Aguilar, a character whose function is analogous to that of the Baron Münchhausen (Giménez, 1960: 46) ${ }^{10}$.

Gerald Thomas commented on Philippe's bush which had taken root on the large pike, and observed that the memorable growth there «is not rationalized by the firing of cherry pips or like at the animal» (Thomas, 1977: 208). Given the relatively late diffusion of hand-held firearms used for hunting, from the sixteenth century onwards (Blackmore, 1971), this is an intriguing theory: and one might also remember de Zúñiga's spear blow. The oak growing from the boar there is only partially a product of human intervention.

${ }^{10}$ Note that the name «don Pedro Manrique, marqués de Aguilar» does not appear consistently in De Zúñiga. This author seems to have mixed together two different characters, perhaps to satirize them. This might be related to failed marriage plans: Guiomar Manrique, the daughter of Pedro Manrique de Lara y Sandoval (ca. 1443-1515), first Duke of Najera, was about to marry Luis Fernández Manrique, II Marquis of Aguilar de Campoo (†1534). The marriage, it seems, did not ultimately take place (Salazar y Castro, 1694). 
Spears predate firearms, historically, and the wound just allows the self-introduction of an acorn in the body by the boar.

However, in his fine study of the Welsh tradition of tall tales (celwydd golau 'the light lie') involving animals, McMullen has shown that twentieth-century fishing stories related to ATU 1889C and the cherry-deer exist. These come from the north of Wales (Gwynedd), and feature a salmon with a tree growing out of its back. Their plot can be summarized as follow: a man «is fishing for salmon and one gets away. Somehow, a sprig from a tree is attached to the salmon, either by [the man] throwing it or the salmon dragging it away while escaping». Later, «when [the man] returns to the area, he notices a tree growing on an island in the river, only to discover that it is actually growing from a salmon». This apparent ecotype of ATU 1889C, McMullen wrote, is «unique to Wales. Indeed, since all three examples [...] seem to originate from the same teller, it is highly probable that the tale is uniquely Welsh» (McMullen, 2015: 46-47, 71, 126-127 and 151).

In the light of Philippe's much earlier French variant, one should be careful on this point. Do we have two independent traditions here? Did Welsh tradition influence Philippe (writing four centuries before)? In any case, there is enough to endorse McMullen's suggestion for establishing a new tale-type 1889C* Tree Grows from Fish. McMullen based his reasoning on the motif of the whale (or turtle) mistaken for an island with (sometimes) trees on it, a motif well attested from Late-Antiquity onwards in Christian, Muslim and Jewish (not to mention Asiatic) religious traditions (Iannello, 2013: 327-533). Admittedly, this bears little resemblances in terms of content and function to the Welsh tall tales in question, beside the miraculous detail of the oversized water animal-island and / or of people being deceived by false floating islands (McMullen, 2015: 47-49, 71, 99 and 107) ${ }^{11}$.

\section{PLANTS GROWING IN AND ON ANIMALS: NATURAL HISTORY}

A few years ago there was an elephant renowned in these [royal] games [and fightings], an animal very dear to the king. The creature had so overfilled its stomach by eating reeds that it became very ill. The doctors could do nothing with their usual medications. The beast put its trunk into its mouth and seemed to be pointing to something troubling it in its stomach. A European doctor noticed this and put his hand into the elephant's mouth, which the animal gladly allowed him to do. The doctor discovered that a reed had taken root in the bottom of the elephant's stomach and had blossomed by putting the leaves; so the doctor first obtained the ingredients to prepare effective remedies [catharctica medicamenta, i.e. purgatives?] to give relief to the beast, then he uprooted the reed, which in the meantime had grown and was green with leaves. The elephant was restored to health, to the great delight of the king and the great profit of the doctor. (Latin text in Kircher, 1667: 79, translation in Kircher, 1987: 72, modified according to Santorelli, 2015: 118)

In his celebrated second-hand description of Asia China monumentis qua sacris qua profanes 2: 5, the German Jesuit Athanasius Kircher (1602-1680) devoted a section to the wealth of the Mughal Empire under Akbar the Great (1542-1605). There, Kircher included this tale about a sick elephant who had a reed take root in its stomach, sprouting leaves there: something «which seem[s] much $[\mathrm{sic}]$ to require confirmation» (Oldenburg,

${ }^{11}$ The (alleged) natural phenomenon of plants and grass generated on the back of cetaceans, note, was included in discussions on BBS affecting animals by several early modern scholars (see e.g. Liceti, 1618: 223; Sennert, 1636: 463; Voigt, 1668: 69). 
1667: 488 $)^{12}$. We do not know from where Kircher took the elephant story, which may originally have been a folktale or a legend circulating at the Mughal court, later carried to Rome by a Jesuit missionary. As Kircher himself stated after having given it: «Numberless such stories could be told» (Latin text in Kircher, 1667: 79, translation in Kircher, 1987: 72).

While the wondrous and the marvellous were often included in Kircher's secondor third-hand portrayal of India (Molina, 2004: 369-370; Flores, 2007: 560-561), the attribution of European nationality to the physician-hero may have been an addition by Kircher or his source $(\mathrm{s})^{13}$. Kircher's memorable story (memorabilem historiam) was, however, taken very seriously by the German doctor and scientist Georg Christoph Petri von Hartenfels (1633-1718): it found its way into the first monograph ever written on the elephant, in a section devoted to the prodigious size and diet of the animal (Latin text in Hartenfels, 1715: 55-56). The historical dissemination of folktales and folk beliefs in early modern works of natural history, between «critical doubt» and «uncritical certainty» (Marzolph, 2019: 200), is a well-known but still poorly studied phenomenon.

Kircher's elephant was briefly compared to BBS affecting humans and / or animals by several subsequent authors. The German physician Alhard Hermann Kummen recalled two seventeenth-century German medical cases: two sick men claimed, respectively, to have vomited or defecated germinated plum kernels, an action that ended their period of sickness (Latin text in Kummen, 1672). Both the Jesuit Father Noël Regnault (16831762) and the Ecuadorian writer Juan Bautista Aguirre y Carbo (1725-1786) (who also relied on Regnault), meanwhile, gathered BBS reports given by «wise men so learned and serious» (Aguirre, 1943: 123): the ancient ivy-deer described by Aristotle and Pliny (see

${ }^{12}$ Both the English natural philosopher Henry Oldenburg (ca. 1619-1677) and François Savinien d'Alquié (who translated Kircher into French) rendered the name of the plant which had grown roots in the elephant's stomach, arundo, with 'sugar cane' - a common food plant for pachyderms (Oldenburg, 1667: 488; Kircher, 1670: 106). Just a few lines before Kircher had spoken about elephants which fight each other for the pleasure of the Mughal Emperor: it is said that the animals are, then, rewarded by Akbar with bundles of sugar cane (saccharum). This oscillation between 'reed' and 'sugar cane' to translate arundo (this perhaps for an unknown vernacular term related to Skt. khanda) should be understood in the context of pre-Linnean botanical taxonomies and/or the logic of languages. On one hand, the term arundo in Latin means reed, cane, rod or any reed like plant in general that can be seen - sugar cane included, in the form arundo saccharifera or simply saccharum (Ernout, Meillet, 2001: 289; De Vaan, 2008: 279-280; compare Provençal, 2010: 112 for the cognate case of qașab within Classical Arabic). On the other hand, Kircher, of course, knew Latin and in his time the difference would be between arundo used as a general term, and arundo saccharifera / saccharum used as specific term. So, 'sugar cane' was perhaps expressed by Kircher with arundo out of context to that end; this similarly to English where one can use the unspecific 'cane' only when the reader / conversation partner already knows that one is talking about sugar cane: "“Cut the cane 'til noon!" said the slave owner, pointing at the sugar cane field».

${ }^{13}$ Indeed, between the seventeenth and eighteenth century, entertaining medical anecdotes circulated in Europe, set in some exotic court and involving expert Western doctors. As in Kircher, these succeed where local physicians fail and are rewarded following their efficacious intervention. Compare Vallisneri (1721: 155-156) and Cantemir (1734: 449) for two versions of a story set at the Ottoman court in Constantinople. The Grand Vizier was convinced that he had noisy flies in his skull (or a fly sitting upon his nose); no one could persuade him that this was a delusion. The patient healed when he was tricked into a cure by a European doctor, who secretly put dead flies in a poultice applied to the Vizier's head (or performed a fake a surgical operation to cut off the fly from the nose). As a reward, the happy Vizier gave many bags of gold to the healer. This was, respectively, the Paduan physician Francesco Spoleti (1647-1712), or a French physician called Le Due (perhaps Antoine Le Duc, a native of Constantinople who later defended a thesis on inoculation at Leyden in 1722: Chais, 1754: 8). I examined some of these medical anecdotes involving 'pious frauds' for treating psycho-behavioural symptoms in Ermacora (2018). 
below); the renowned seventeenth-century case of the Spanish boy with a thorn that had grown in his body (see Ermacora, 2020); a German man who occasionally urinated small mushrooms, and two German and Dutch men in whose bodies mushrooms were found. In all of these, the authors speculated, grains could have penetrated inside the body with air, food or drink and found the necessary provision there, thanks to chyle or other bodily juices, thus taking root and growing (Regnault, 1732: 353-354; Aguirre, 1943: 123).

Finally, German author Johann Zahn's (1641-1707), in his 1696 natural history book entitled Speculae physico-mathematico-historicae 2, 11: 13, was able to compare Kircher's elephant to a deer with chamomile growing on its head (Latin text in Zahn, 1696: 232). The deer story had surfaced ten years before, in 1686, when a German physician, Christian Franz Paullini (1643-1712), had published an abridged edition of a compilation of curiosities entitled Breviarium rerum memorabilium 64. There, it is stated that, in the year 1180, «Sigebodo von Schnakenburg saw in Lotharingia a deer that had been taken. Between the antlers of the head a beautiful chamomile had bloomed with flowers giving out a pleasing smell» (Latin text in Paullini, 1686: 207).

Paullini claimed that the Breviarium was written between the twelfth and the thirteenth century by two obscure monks of the Benedictine monastery of Corvey, in Westphalia: Isibordus von Ameluxen and Alexander Insulanus (Duval, 1824). The compilation, however, must be considered as an invention by Paullini himself. Paullini was a prolific forger of pseudohistorical documents mixing 'curious' medicine (designed for entertainment) and monastic history (Backhaus, 1905: 23-27; Wallnig, Stockinger, 2010: 303, 977; Schachenmayr, 2013: 277-280). In the early modern period, BBS were often included in learned discourses on excrescences or 'super-plants' (in Francis Bacon's terminology: Jalobeanu, 2018), i.e. vegetable-like forms of life growing parasitically on stones, skulls, walls, trees, humans and, of course, animals. 'Super-plants' were thought to generate spontaneously from humidity, putrefaction and / or the sap excreted by the host (Ermacora, 2020).

Some letters written in the years 1635-37 cited an early modern treatise on the birth of plants and other vegetables on and inside the bodies of animals, written by a certain Liret / Liretto (Tamizey de Larroque, 1893: 576-77, 583 and 593; Lhote, Joyal, 1989: 218-219). We now know (Ermacora, 2020) that this is a reference to Fortunio, Liceti's (1577-1657) encyclopaedic treatise on spontaneous generation De spontaneo viventium ortu 3: 28-30. Liceti, an Italian physician, included in his work a section on BBS reports involving humans and animals and was widely read on both sides of the Alps (Latin text in Liceti, 1618: 222-223; see Hirai, 2011: 123-150 on Liceti and France).

There are, in fact, several historical folklore-sounding examples of plants growing on living deer: if chamomile can grow on a deer's head, so can ivy. In their works, Liceti and other Renaissance colleagues writing on BBS noted that reports of thick green ivy found growing on deer's antlers were mentioned by Aristotle, Theophrastus and Pliny - among others (list of sources in Louis, 1967: 246; Einarson and Link in Theophrastus, 1976: 39; Schnieders, 2013: 23; Schnieders in Aristotle, 2019: 725-726). These authorities, in turn, were commented on for centuries by learned authors ranging from scholars of literature to natural scientists; as if, as one of them put it, «The story is told more frequently than the interest of the simple fact would seem to warrant» (Thompson in Aristotle, 1910: 84).

Aristotle wrote in his fourth-century BC zoological work of natural history Historia animalium 9: 5, that, "when it is no longer painful [for young deer] to rub [their horns] on the trees, then they leave [the thick undergrowth where they were hiding] because they feel confident since they have means of defence». Aristotle, thus, relates «quite casually» (Schnieders, 2013: 23) the following anecdote: "And before now an 


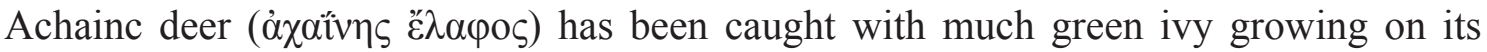
horns, showing that the horns were tender when it was implanted as if in green wood» (Greek text and translation in Aristotle, 1991: 242-243) ${ }^{14}$.

Aristotle's information, which perhaps came to him by hearsay from hunters (Schnieders, 2013: 23; Schnieders in Aristotle, 2019: 242), was influential and has long puzzled commentators: from Athenaeus of Naucratis, who wrote of this in his late second-century antiquarian work Deipnosophistae 8: 48 ('where did [Aristotle] see ivy growing from a deer's horn?': Greek text and translation in Athenaeus, 2008: 114-115), to modern researchers examining the issue of the presence of folktales and folk (dis) belief in Aristotle ${ }^{15}$. Indeed, in Antiquity the ivy-deer was taken as a wonder of nature by those who had read Aristotle and cropped up, as Leonhard Dittmeyer put it, in the «most absurd» stories, i.e. the strange and the wondrous which needs to be shared but not to be explained (Dittmeyer, 1887: 70).

Depending on Aristotle's account, but summarizing it, are in fact the paradoxographical authors interested in the (bizzarre) animal world and life sciences (Eleftheriou, 2018a: 141-143 and 230; 2018b: 84-86). These are pseudo-Antigonus of Carystos' Historiae mirabiles 29, dating ca. $240 \mathrm{BC}$ (if it is not a tenth-century Byzantine compilation of ancient and medieval texts as maintained by Musso, 1986): «A female deer

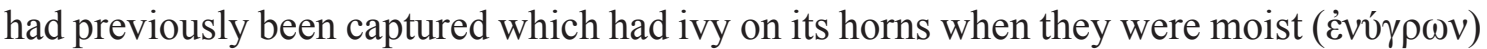
[= tender?]» (Greek text in Giannini, 1966: 35; translation in pseudo-Antigonus, 2014); or the pseudo-Aristotle' Mirabilium auscultationes 5, of difficult dating (third century $\mathrm{BC}$ ?): «In the place of the horns ivy may often be seen to have grown on [deer]» (Greek text and translation in Aristotle, 1936: 240-241).

The detail of the wet / humid horns in the pseudo-Antigonus is not present in Aristotle and can be considered, perhaps, the result of a bad reading of the original (Eleftheriou, 2018b: 86); while pseudo-Aristotle appears, indeed, as a «clumsy summary» of Aristotle (Vanotti in pseudo-Aristotle, 2007: 144). We also see how, in a typical fashion, Aristotle's information increased its explicative value: from the particular to the general. In the pseudo-Aristotle the ivy is said to have grown on many deer and, thus, the phenomenon is described as being relatively recurrent. This is a process which can also be found in Aristophanes of Byzantium's (ca. 265 / 257-190 / 180 BC) summary of Aristotle's study on animals, the Historiae animalium epitome 2: 489: «yet several times, it is said, deer appeared also with ivy grown on its horns» (Greek text in Aristophanes of Byzantium, 1885: 127). Does this means that more accounts on ivy-deer were circulating, independent of Aristotle's, at the time when the Greek authors referenced above were

${ }^{14}$ Aristotle does not say what happened to the deer later; thus, the Italian humanist Giulio Cesare Scaligero (1484-1558) sarcastically observed that the ivy on the horns did not ultimately improve the condition of the animal: when the ivy disappeared, the deer was most likely killed by a knife (culter) (Latin text in Scaligero, 1566: 153). It is also unclear whether the adjective $\alpha \chi \alpha i i v \eta \varsigma$ refers to a geographical place, a specific deer species or whether it expresses the age of the animal (Hellmut Flashar in Aristotle, 1972: 72-73; Vanotti in pseudo-Aristotle, 2007: 144; Schnieders, 2013: 23).

${ }^{15}$ See e.g. de Villebrune in Athenaeus, 1789: 312-313; Cuvier in Pliny, 1830: 449; Allan, J. H and C. S. H. Allan, 1848: 131; Barthélemy-Saint-Hilaire in Aristotle, 1883: 153; Dittmeyer, 1887: 70; Louis, 1967: 98-99; Preus, 1975: 278; Schnieders, 2013: 23-25; Schnieders in Aristotle, 2019: 242 and 725-726. Commenting on Aristotle's ivy-deer, one author referred the reader to a review article, written by the French naturalist Fougeroux de Bondaroy (1732-1789), «on plants which vegetate on living animals» (ArmandGaston Camus in Aristotle, 1783: 174). This connects to a topic which has nothing to do with BBS: the eighteenth-century discussions of plants (= fungi) which can grow on insects —also labelled 'animal plants' (plantes animales) (Fougeroux de Bondaroy, 1769; 1772; see Lu, 2017: 132-137). 
writing? Was Aristotle's ivy-deer alone? Or, in other words: how important was Aristotle's authority for those authors who split the single ivy-deer into many?

Texts related to paradoxography, treating but not focused on marvels, are interesting in this light. In a small section on phenomena with an extraordinary ( $\pi \alpha \rho \alpha \delta o \xi$ ó $\tau \varepsilon \rho o v)$ character contained in his fourth- / third-century BC botanical work De causis plantarum 2, 17: 4, Theophrastus is chary about Aristotle's ivy-deer. Theophrastus observes, in fact, that «the instance observed of [ivy] growing on the horns of a stag is of a more unexpected sort». This is, for Theophrastus, a strange phenomenon directly comparable to instances of plants growing on something else (e.g. other plants) and not on the ground, instances «that strike people as having rather the character of rarities and portents». Although Theophrastus does not dismiss the miraculous nature of Aristotle's ivy-deer, of which he evidently knows no parallels, he is chary about the report's veracity:

For when the seed falls on some spot that has become earth-like through decomposition, it sprouts and then lives by taking the food that belongs to the tree; and it is not unreasonable that this this is also what happened with the ivy that was growing on the horns, supposing the report true. (Greek text and translation in Theophrastus, 1976: 338-339; see also Sharples, 1995: 47)

It may be that Theophrastus (a botanist) and Aristotle (a zoologist) had personally exchanged information about the ivy-deer, though, in respect of Aristotle, Theophrastus endeavours «to rationalize the supernatural [...] within the confines of nature» (Schnieders, 2013: 23; see also Schnieders in Aristotle, 2019: 242 and 726). According to Theophrastus, in fact, putrefactive / rotting processes play a role in providing a breeding ground for the ivy. Thus, some old collectors of curiosities (e.g. Voigt, 1668: 69) briefly compared the ancient ivy-deer to the 'vegetable power' of ungulates' horns reflected in a superstition which can be found in a very large corpus of statements of beliefs/disbeliefs, attested from Greco-Roman times to contemporary folk traditions: if ram horns are pounded and then buried (whole or in pieces) in the ground, there asparagus will grow (see, on this, CollettSandars, 1877: 62; Scarborough, 2002: 184; Lelli, 2014: 163). The sheer ubiquity of horns of various types in medicine / magic suggests that they can have a special 'mineral' quality which brings them to closely resemble soil. Is this the background to the ancient asparagus superstition and to Aristotle's ivy-deer?

Finally, Pliny takes up Aristotle's report and relates, in his Naturalis historia 8: 50 , in a different rational key to Theophrastus, that «stags have been caught with green ivy on their antlers, that ivy has been grafted on the tender horns as on a log of wood as a result of rubbing them against trees (ex attritu arborum) while testing them» (Latin text and translation in Pliny, 1940: 84-85 $)^{16}$. Discussing these loci classici, medieval ${ }^{17}$ and

${ }^{16}$ Note that Schenda (1958: 54) speculated that Pliny influenced a sixteenth-century tall tale from Philippe le Picard in which squirrels nested in the antlers of a stag.

17 One might mention here Bartholomaeus Anglicus' great encyclopedic treatise De proprietatibus rerum 18: 29, written 1230-1247, which claims: «sometime [the deer] froateth [its horns] against a trée that is compassed with Iuie, or with Weathwinde, and their hornes be snarled and fastened in it, and be sometime so taken» (Latin text in Anglicus, 1601: 1046, translation in Anglicus, 1582: 357v). Although Bartholomaeus uses Pliny and Aristotle, this is rather original information which, perhaps, conflated different passages and / or came to Bartholomaeus from an Arab work (see Stetkevych, 2002: 110-111 for unicorns/antelopes). During the 14th century, note, Bartholomaeus' work was translated into the most important vulgar tongues, for example Middle French (1372) and Middle English by John Trevisa (1398) (text in Anglicus, 1975). 
early modern commentators have long debated if the phenomenon of ivy spontaneously growing on antlers can really happen - apparently, nobody had found any empirical proofs of it in nature or went beyond simply piling up indirect evidence of BBS (Liceti, 1618: 222; 1640: 298-299; Nieremberg, 1635: 31; Sennert, 1636: 460-465; Kircher, 1664: 334-335; de Villebrune in Athenaeus, 1789: 312-313; Michelet, 1872: 402; Aguirre, 1943: 123; Stensen, 1997: 28). Indeed, "If the Ancients witnessed this singularity, it is strange that this wonder was denied to the Moderns» (Anonymous, 1763: 870). It is, thus, worth looking in more detail at a few of these commentators.

First, there was spontaneous generation. According to a later edition of Italian polymath Giovanni Battista della Porta's (1535-1615) best-selling book Magiae naturalis 3: 1, first published in 1558, it was «impossible to think how any Ivy seed could get in there». Della Porta was skeptical that an ivy seed could have spontaneously grown on the horns: «And whereas some allege, that the Hart might have rubbed his Horn against some Ivy roots, and so some part of the Horn being soft and ready to Putrify, did receive into it some part of the root, and by this means it might there grow, this proposition carries no show of probability or credit with it» (Latin text in della Porta, 1591: 101, translation in della Porta, 1658: 59).

For Liceti and Kircher, however, two Renaissance authors (among many) deeply interested in BBS in the context of the theory of spontaneous generation (Ermacora, 2020), the matter was somehow simpler. They echoed Theophrastus and Pliny and believed that through the friction on trees the deer took ivy seeds on its hairy head. These germinated there thanks to the heat of the environment (calore ambientis), dust (pulveribus) and vaguely identified natural liquids (sweat, dew, nocturnal moisture, etc.) which mixed together and become like soil. Admittedly, this was not conventional spontaneous generation. To quote Kircher's monumental book of speculative science Mundi subterranei tomus II 12, 1: 7: «If, however, we place a deer [in] an ivy pasture (pabulo hederae), by the virtue of the female [seeds] hidden in that nourishment, thanks to the internal heat of the deer, then it is possible to tell of spontaneous growths: but the first [option] is more probable» (Latin text in Kircher, 1664: 334; see also Liceti, 1618: 222; 1621: 243$)^{18}$.

Other early modern authors were more interested in the experimental method, though they also lingered (as Theophrastus, Liceti and Kircher) on the erroneous botanical assumption that ivy is a parasitic plant which leeches nutrients from wood. So the English writer and statesman Francis Bacon (1561-1626), in his 1626 natural history Sylva sylvarum, found "scarce credible» that ivy could grow out of a stag's horn: he proposed to put fennel-, mustard- and rape-seeds «into some little holes made in the horns of stags or oxen, to see if they will grow» (Bacon, 1864: 408; see Jalobeanu, 2018: 465 for this in the wider context of Bacon's scientific discourses on 'super plants'). One century later, Georges-Louis Leclerc de Buffon (1707-1788) wrote much the same, in the sixth book (1756) of his monumental work of natural science Histoire naturelle: «If this fact be true, and it may easily be determined by experiment, an analogy still more

\footnotetext{
${ }^{18}$ Unlike Kircher, Liceti had previously considered both possibilities as equally valid: he did not choose the most likely (Latin text in Liceti, 1618: 222). Relying on Liceti, the German physician Daniel Sennert (1572-1637) instead inclined towards the first (Neque ratio ulla datur [...] neque caussa dari potest) (Latin text in Sennert, 1636: 460-465).
} 
intimate will be established between the wood of the stag and that of trees» (Leclerc, 1785: 97-98) ${ }^{19}$.

The French physician and philologist Jean-Baptiste Lefebvre de Villebrune (17321809), meanwhile, apparently unaware of Pliny, tried to 'save' Aristotle from the charge of being gullible through a complicated set of reasoning which mixed euhemerism and folklore. Much as Kircher, de Villebrune believed that the Achainc deer, rubbing itself against trees, «had introduced into the substance of its new horns an ivy seed fallen from its [original] place, and that, by taking root, [the seed] had vegetated until the antlers were shed». What is more, in order to strengthen the argument that «Animal substances can $[\ldots]$ in some circumstances favour the development of vegetables», Lefebvre quoted several BBS reports involving humans from contemporary French medical literature ${ }^{20}$. Aristotle, de Villebrune concluded, «did not say anything so absurd» (de Villebrune in Athenaeus, 1789: 312-313; see, similarly, Aguirre, 1943: 123).

«Ivy cannot, of course, grow on antlers» (König and Winkler in Pliny, 1976: 216; pace Carlyle's, 1857: 87 «good evidence» based on Aristotle alone). Therefore, today, most commentators of Aristotle move to one of two extremes: either the ancient ivydeer is dismissed as a fable showing Aristotle's superstitious credulity (Allan, J. H and C. S. H. Allan, 1848: 131; Louis, 1967: 98-99); or Aristotle is made a champion of the «critical-rational spirit» (kritisch-rationalen Geist) assuming, doubtfully, that Aristotle questions - but how exactly? - the truth of the ivy-deer because what normally interests him are the biological facts (Schnieders, 2013: 23-25; Schnieders in Aristotle, 2019: 242 and 725-726).

Other commentators have adopted a more subtle strategy as they went back to Pliny's rational discourse grounded, more strongly, in natural history and deer scratching on trees. The only difference in this respect is that they added to it some rather vague 'magical significance' carried by the figure of the ivy-crowned deer, «something which Aristotle quite disregards in the passage». They also dismissed the fact that ivy could take root on animal horns, as maintained by Pliny, Kircher and Lefebvre: «of course [the ivy] did not grow there, the stag had been [just] rubbing his horns against an ivy-covered tree»» (Preus, 1975: 35, 278; see, similarly, also Dombrowski, 1922: 111; König and Winkler in Pliny, 1976: 216).

In other words, these scholars thought that Aristotle's ivy-deer might have some foundation in the natural world. Green leaves and tendrils of ivy had accidentally remained stuck between the horns of the deer / stag, adhering to them and were mistaken for ivy spontaneously grown on the animal head. This, in turn, was magical or quasi-religious for observers. Ivy and deer / fawn were indisputably special in the Dionysian cult (MaxwellStuart, 1971), and so «in Bacchanalian processions the heads of stags were sometimes

19 This affinity — already hinted at, as we have seen, by Aristotle, Theophrastus and Pliny - was endorsed by James Madison (1751-1836) in some 1786 unpublished notes on Buffon's work (Madison, 1975: 32), and by a German encyclopaedist: «just as [ivy] receives its nourishment from the juice of the tree on which it grows, it extracts from the horn the juices necessary for its preservation» (Müller, 1790: 583; see, similarly, also Carlyle, 1857: 87).

${ }^{20}$ These are: surgeons were surprised to discover that a tumour in a child's right nostril was, in reality, a pea which had sprouted there «ten or twelve roots one inch long»; a peasant vomited, with an emetic, some oat grains which he had swallowed nine months before and «which had germinated in his stomach»; a man died because of the cherry stones that he had swallowed more than a year before: these «had grown a germ of several lines» inside his stomach (de Villebrune in Athenaeus, 1789: 312-313). De Villebrune summarized Sigaud de La Fond (1781: 446-449) here. 
decorated with garlands of ivy» (Allan, J. H and C. S. H. Allan, 1848: 131) / «probably a stag or fawn with the Dionysiac plant about its horns would be looked on as something portentous» (Thompson in Aristotle, 1910: 84; see also Schnieders, 2013: 24; Schnieders in Aristotle, 2019: 726).

It is unfortunately not possible to add further context to Aristotle's passage, though a last (and minor) interpretation of the ivy-deer, more radical in terms of realism, still needs to be mentioned. The whole story could be a 'distorted observation' of Perückengehörns, i.e. a genetic deformity of a male deer whose failed distribution of testosterone leads to an abnormal growth on its antlers (Flashar in Aristotle, 1972: 73). Were Aristotle and Theophrastus, thus, explaining a similar malformation of a deer as natural against those who preferred a supernatural explanation of it (as hinted by Schnieders, 2013: 25)? Maybe $^{21}$. The supposed credulity of the ancients, unable to comprehend the reality around them, has long been a stopgap for scholars.

\section{CONCLUSION}

In my first paper on BBS traditions (Ermacora, 2020) I observed that plants inside us are seen as agents of disease, much as animal parasites are. The capacity of the seed to grow in a person represents, in literal terms, an «intrusion of nature» (Ziegler, 1998: 46). Victims of BBS are normally not happy to have plants and other vegetables sprouting from their bodily orifices, growing from their face, stomach, etc. This disease causation perspective (aetiology) and the literal and negative character of BBS is, in my view, crucial for fully understanding the nature of the materials in question. I have essentially rejected sexual / embryological readings (such as analogies between embryos and plants); as well as readings centred on monstrosity (such as human / plant hybridism) (Ermacora, 2020) $)^{22}$.

${ }^{21}$ In the Monstrorum historia by Italian naturalist Ulisse Aldrovandi (1522-1605), a treatise on zoological and human physical abnormalities published posthumously in 1642, there is a woodcut of a monstrous multi-antlered male deer (Capreolus polyceros). We learn from Aldrovandi that the original image had been sent to him «by a Serene Bavarian duke». On top of the animal's head there are seventeen abnormally formed antlers «some with ramifications, some without» - depicted as plant branches (Latin text in Aldrovandi, 1642: 424-425). The woodcut has no context linked to it: the use in Aldrovandi of printed drawings, illustrations and woodblock matrices which originally had a different purpose and history, is a rich topic (Olmi, Simoni, 2018). What the author of the image had originally in mind was, perhaps, a hunting story related to ATU 1889C? Or was the deer real and a factual result of insufficient testosterone? This was suggested, relying on scholarly zoological literature, by Heinrich Geissler who examined the history of the image: it derives from a 1589 Bavarian painting by Hands Hoffmann (ca. 1530-1592) who, in turn, copied a painting (ca. 1578) depicting a hunting trophy made by 'Monogrammist IZ' (Jörg Ziegler?). It is possible that Hoffmann made more copies of this painting, and that one ended up in the home of an unnamed Bavarian duke and, then, of Aldrovandi (Geissler, 1986-1987: 101-105). The image of the deerhead is, however, consistent with the many wondrous animal specimens exhibited (preserved or painted) in Renaissance Wunderkammers because of some bodily deformity (Kaufmann, 1988: 85 and 216; Ujvári, 1993: 101-102). A «head of a roe deer, whose wood was monstrous» was located, for instance, in Swiss scholar Johann Jakob Scheuchzer's (1672-1733) cabinet of curiosities (Scheuchzer, 1735: 295).

${ }^{22}$ To be clear: I am not interested in doubtful medical explanations for plants growing inside the body or on its surface. Suffice it to say that there are fungal parasites (dermatophytes and keratinophilic fungi); fungal pneumonia (an infection of the lungs by fungi); and 'cutaneous horns', uncommon protrusions of keratotic material which can grow virtually anywhere on the body, and which can end up being several centimetres long (Bondeson, 2000: 120-140). None of these, of course, are plants in a biological sense, though they might have (but how?) inspired comparisons or caused confusion. 
Of course, this must not be taken in absolute terms. The connection between disease and BBS can be explicit as in Kircher's aforementioned tale of the ill elephant, or can remain implicit as with Henry Julius' 'pomegranate-man' and the Japanese rakugo story of the cherry seeds. There is a sort of punitive pattern at work there: in both cases, the victims are parasitized by BBS because of their excessive fondness for the fruits with their seeds. The evidence presented above shows that the image of the plant growing inside the body, and / or on its surface, can be variously adapted and bears «different functions in different genres» (McMullen, 2015: 48); not least according to positive Christian associations which equate goodness to beautiful flowers such as roses and lilies, and the taste for mixing exaggeration and reality: as is evident in tall tale ATU 1889C, its fish variant $1889 \mathrm{C}^{*}$ and grass / chamomiles / ivy growing on ruminant mammals. In BBS narratives, the focus on disease is not as strong as in stories featuring animals within the body (Ermacora, 2015; Ermacora, Labanti, Marcon, 2016): we have, instead, a lighter, more playful tradition.

\section{BIBLIOGRAPHY}

Aguirre, Juan Bautista (1943): Poesias y obras oratorias, Gonzalo Zaldumbide and Aurelio Espinosa Pólit (eds.), Quito, Clásicos Ecuatorianos.

Alberti, Francesca and Bodart, Diane H. (2018): «Introduction», in Rire en images à la Renaissance, Idd. (eds.), Thurnout, Brepols, pp. 15-44.

Alcotт, William A. (1838): The Young House-Keeper or Thoughts on Food and Cookery, Boston, G. W. Light.

Alcripe, Philippe d' (1983): La nouvelle fabrique des excellents traits de verité..., Françoise Joukovsky (ed.), Geneve, Droz.

Alden, Mills H. (1872): «Editor's Drawer», Harper's New Monthly Magazine, 270, 45, pp. 794-800.

Aldrovand, Ulisse (1642): Monstrorum historia..., Bologna, Nicolaus Thebaldinus.

Allan, John H. and Allan, Charles S. H. (1848): Lays of the Deer Forest..., II, London / Edinburgh, Blackwood and Sons.

Anderson-Green, Paula H. (1983): «Folktales in the Literary Work of Harden E. Taliaferro. A View of Southern Appalachian Life in the Early Nineteenth Century», North Carolina Folklore Journal, 31, pp. 65-75.

Anglicus, Bartholomaeus (1582): Batman vppon Bartholome his booke De proprietatibus rerum..., Stephen Batman (ed.), London, Thomas East.

Anglicus, Bartholomaeus (1601): De genuinis rerum coelestium..., Jiří Barthold Pontanus z Breitenberka (ed.), Frankfurt, Richter.

Anglicus, Bartholomaeus (1975): On the Properties of Things. John Trevisa's Translation of Bartholomaeus Anglicus De proprietatibus rerum. A Critical Text, II, Maurice C. Seymour (ed.), Oxford, Clarendon Press.

AnONYmous (1763): «Review of L'école de la chasse aux chiens courans, by JeanBaptiste Le Verrier de la Conterie», Journal des Sçavans, December, pp. 866-874.

Anonymous (1764): «Caution About Eating of Fruit», The Weekly Amusement, 4 August, pp. $515-516$.

Anonymous (1870): «Raspe, Rudolph Erich», in Id., A Critical Dictionary of English Literature and British and American Authors..., II, Austin S. Allibone (ed.), London, Trübner / Philadephia, Lippincott, pp. 1741-1743. 
Anonymous (1872a): «Peripatetic Pastures», Sacramento Daily Union, 42, 7376, 4 January.

Anonymous (1872b): «A “Tall” Story», Stroud News and Gloucestershire Advertiser, 28 Friday.

Anonymous (1872c): «A Walking Pasture», The Youth's Companion, 151, 7 March, p. 80 .

Aristophanes of Byzantium (1885): Aristophanis Historiae animalium epitome..., Spyridon P. Lampros (ed.), Berlin, Reimer.

Aristotle (1783): Histoire des animaux, II, Armand-Gaston Camus (ed.), Paris, Desain.

Aristotle (1883): Histoire des animaux, III, Jules Barthélemy-Saint-Hilaire (ed.), Paris, Hachette. DOI: https://doi.org/10.5962/bhl.title.61676

Aristotle (1910): The Works of Aristotle. Historia animalium, IV, D'Arcy W. Thompson (ed.), Oxford, Clarendon Press. DOI: https://doi.org/10.5962/bhl.title.147382

Aristotle (1936): Minor Works..., Walter S. Hett (ed.), Cambridge, MA, Harvard University Press.

Aristotle (1972): Mirabilia, Hellmut Flashar (ed.), Berlin, Akademie-Verlag.

Aristotle (1991): History of Animals, Volume III, Books 7-10, David M. Balme (ed.), Cambridge, MA, Harvard University Press.

Aristotle (2019): Historia animalium. Buch VIII und IX, Stefan Schnieders (ed.), Berlin / Boston, De Gruyter.

Aristotle (PSEUdo) (2007): Racconti meravigliosi, Gabriella Vanotti (ed.), Milano, Bompiani.

Atelier Vincent De Beauvais (2015): Atelier Vincent de Beauvais. URL: < http://atilf.atilf. $\mathrm{fr} / \mathrm{bichard} />$.

Athenaeus (1789): Banquet des savans ..., Jean-Baptiste Lefebvre de Villebrune (ed.), III, Paris, Lamy.

Athenaeus (2008): The Learned Banqueters, Volume IV, Books 8-10.420 , Olson S. Douglas (ed.), Cambridge, MA, Harvard University Press. DOI: https://doi. org/10.4159/DLCL.atheneus_grammarian-learned_banqueters.2007

Backhaus, Johannes (1905): Die Corveyer Geschichtsfälschungen des 17. und 18. Jahrhunderts. Teil 1, Paullini, Berlin, Friedrich-Wilhelms-Universitat.

BACON, Francis (1864): Sylva sylvarum or, a Natural History in Ten Centuries, in The Works of Francis Bacon, Baron of Verulam Viscount of St. Alban, and Lord High Chancellor of England, James Spedding, Robert L. Ellis, and Douglas D. Heath (eds.), IV, New York, Hurd and Houghton.

BADDAM, Benjamin (1739): «Review of Balls Voided by Stool, by Ralph Thoresby», Memoirs of the Royal Society..., 4, pp. 481-482.

BAтH, Michael (1979): «The Legend of Caesar's Deer», Medievalia et Humanistica, 9, pp. 53-66.

Baughman, Ernest W. (1966): Type and Motif-Index of the Folktales of England and North America, The Hague, Mouton. DOI: https://doi.org/10.1515/9783111402772

BENDER, Émile and Vermorel, Victor (1890): Le vigneron moderne. Établissements et culture des vignes Nouvelles, Montpellier, Coulet.

Berlioz, Jacques, Collomb, Pascal and Polo de Beaulieu, Marie-Anne (2001): «La face cachée de Thomas de Cantimpré. Complément à une traduction française récente du Bonum universale de apibus», Archives d'Histoire Doctrinale et Littéraire $d u$ Moyen Âge, 68, pp. 73-94. DOI: https://doi.org/10.3917/ ahdlm.068.0073 
Bernitz, Berhnard M. (1671): «Ruta muraria et mucus crustaceus in cranio humano», Miscellanea Curiosa; sive, Ephemeridum Medico-Physicarum Germanicarum, 2, pp. 96-106.

Bethke, Robert D. (1981): Adirondack Voices. Woodsmen and Woods Lore, Urbana, University of Illinois Press. DOI: https://doi.org/10.2307/767662

Bilanchone, Catherine M. (2006): «Lankershim, Isaac (1818-1882)», in Encyclopedia of Immigration and Migration in the American West, Alexandra Kindell and Gordon M. Bakken (eds.), I, Thousand Oaks, CA, Sage, pp. 379-380.

Blackmore, Howard L. (1971): Hunting Weapons from the Middle Ages to the Twentieth Century, London, Barrie \& Jenkins.

BLAIR, Walter (1993): «AGerman Connection, Raspe's Baron Munchausen», in Id., Essays on American Humor, Blair Through the Ages, Hamlin Hill, Madison, University of Wisconsin Press, pp. 57-71.

BlÜMmL, Emil C. (1906): «Motivengeschichte des deutschen Volksliedes. I: Die Lilie als Grabesptlanze», Studien zur Vergleichenden Litteratur-Geschichte, 6, pp. 409427. DOI: https://doi.org/10.1515/bgsl.1906.1906.31.1

Blurton, Heather and Johnson, Hannah (2015): «Reading the Prioress's Tale in the Fifteenth Century: Lydgate, Hoccleve, and Marian Devotion», The Chaucer Review, 50, 1-2,pp. 134-158. DOI: https://doi.org/10.5325/chaucerrev.50.1-2.0134

Blurton, Heather and JoHnson, Hannah (2017): The Critics and the Prioress: Antisemitism, Criticism, and Chaucer's Prioress's Tale, Ann Arbor, MI, University of Michigan.

Bondeson, Jan (2000): The Two-Headed Boy and Other Medical Marvels, Ithaca, Cornell University Press.

Borel, Pierre (1656): Historiarum, et observationum medicophysicarum..., Paris, J. Billaine.

BoyD, Beverly (1957): «The Literary Background of Lydgate's The Legend of Dan Joos», Modern Language Notes, 72, 2, pp. 81-87. DOI: https://doi.org/10.2307/ 3043297

Braunschweig-Wolfenbüttel, Heinrich Julius von (1967): Von einem Weibe. Von Vincentio Ladislao. Komödien, Brauneck Manfred (ed.), Stuttgart, Reclam.

Broughton, Laurel (2005): «The Prioress's Prologue and Tale», in Sources and Analogues of the Canterbury Tales, Robert M. Correale and Mary Hamel (eds.), II, Cambridge, Brewer, pp. 583-648.

Broughton, Laurel (2006): «The Rose, the Blessed Virgin Undefiled. Incarnational Piety in Gautier's Miracles de Nostre Dame», in Gautier de Coinci: Miracles, Music, and Manuscripts, Kathy M. Krause and Alison Stones (eds.), Turnhout, Brepols, pp. 281-299. DOI: https://doi.org/10.1484/M.TCNE-EB.3.4040

Burger, Harald (1968): «Herzog Heinrich Julius von Braunschweig "Vincentius Ladislaus", zu einer Kontroverse der Literaturkritik», Literaturwissenschaftliches Jahrbuch, 9, pp. 65-83.

C. H. (1759): «Caution Against Eating Fruit», in The Grand Magazine of Magazines or Universal Register, 2, p. 50.

CAEsar, Julius (1917): The Gallic War, Henry John Edwards (ed.), Cambridge, MA, Loeb Classical Library. DOI: https://doi.org/10.4159/DLCL.caesar-gallic_wars.1917

CANTEMIR, Dimitrie (1734): The History of the Growth and Decay of the Othman Empire..., Nicolas Tindal (ed.), I, London, John James \& Paul Knapton.

Carlyle, Thomas (1857): «Deer. Part. II», Fraser's Magazine for Town and Country, 56, pp. 72-89. 
Chais, Charles (1754): Essai apologétique sur la méthode de communiquer la petite vérole par inoculation..., La Haye, Pierre de Hondt.

Chevalier, Máxime (1999): Cuento tradicional, cultura, literatura (siglos XVI-XIX), Salamanca, Universidad de Salamanca.

Collett-Sandars, William (1877): «Asparagus», The Gentleman's Magazine, 241, pp. 57-75.

Craig, Raymond (ed.) (1987): The Humor of H. E. Taliaferro, Knoxville, University of Tennessee Press.

CurTs, Patricia D. (1948): «The Baron Munchausen», New York Folklore Quarterly, 4, 2, pp. 97-108.

Davies, Sioned (ed.) (2007): The Mabinogion, Oxford, Oxford University Press.

De Bruyn, Eric. C. H. (2011): TM9, Twee paartjes. URL: <http://www.bloggen.be/ ericgldebruyn/archief.php?ID=1082715>.

De Navarro, José M. (1972): The Finds From the Site of La Tène. Scabbards and the Swords Found in Them, I, London, Oxford University Press.

De VaAn, Michiel (ed.) (2008): Etymological Dictionary of Latin and the Other Italic Languages, Leiden, Brill.

Della Porta, Giovanni Battista (1591): Magiae naturalis..., Frankfurt, Andreae Wecheli Heredes.

Della Porta, Giovanni Battista (1658): Natural Magick..., London, Thomas Young and Samuel Speed. DOI: https://doi.org/10.5479/sil.82926.39088002126779

DitTMEYER, Leonhard (1887): «Die Unechtheit des IX. Buches der Aristotelischen Tiergeschichte», Blätter für Das Bayer. Gymnasialschulwesen, 23, 10, pp. 65-79.

Dombrowski, Ernst (1922): «Die Geweihbildung unserer Hirscharten in der älteren zoologischen und jagdlichen Literatur», Jahrbuch für Jagdkunde, 6, pp. 107-17.

Ducati, Pericle (1923): La situla della Certosa, Bologna, Stabilimenti Poligrafi Riuniti.

Duval, Amaury (1824): «Alexandre de L'Isle, moine de Corbie», in Histoire littéraire de la France..., XVI, Paris, Didot, Treuttel et Wurzt, pp. 515-516.

Eleftheriou, Dimitra (2018a): Pseudo-Antigonos de Carystos, Collection d'Histoires Curieuses. Introduction-Édition-Traduction, I, PhD Dissertation, Paris Nanterre University.

Eleftheriou, Dimitra (2018b): Pseudo-Antigonos de Carystos, Collection d'Histoires Curieuses. Commentaire, II, PhD Dissertation, Paris Nanterre University.

Ellisen, Adolf (1849): «Einleitung zu dieser neuen Ausgabe», in Erich R. Raspe, Des Freih. v. Münchhausen wunderbare..., Gottfried A. Bürger (ed.), Göttingen / Dieterich / Berlin, Enslin, pp. III-XXVI.

Ermacora, Davide (2015): «Pre-Modern Bosom Serpents and Hippocrates' Epidemiae 5, 86: A Comparative and Contextual Folklore Approach», Journal of Ethnology and Folkloristics, 9, 2, pp. 75-119.

ERmaCora, Davide (2018): «Embedded Pins and Migratory Needles: A Historical Folklore Perspective. Part I», Contemporary Legend, 8, pp. 41-85.

Ermacora, Davide (2020): «Botanical Bosom Serpent Traditions», Folklore, Forthcoming.

Ermacora, Davide, Labanti, Roberto and Marcon, Andrea (2016): «Towards a Critical Anthology of Pre-Modern Bosom Serpent Folklore», Folklore, 128, 3, pp. 286304. DOI: https://doi.org/10.1080/0015587X.2016.1175763

Ernout, Alfred and MeILlet, Antoine (eds.) (2001): Dictionnaire étymologique de la langue latine. Histoire des mots, Paris, Klincksieck.

Eyssen, Jürgen and Dietmar, Storch (eds.) (1983): Niedersächsisches Lesebuch, Hildesheim, Gerstenberg. 
Fabri de Peiresc, Nicolas-Claude (1893): Lettres de Peiresc. 1626-1637, Philippe Tamizey de Larroque (ed.), IV, Paris, Imprimerie Nationale.

Fabri de Peiresc, Nicolas-Claude (1989): Lettres à Cassiano dal Pozzo, 1626-1637, JeanFrançois Lhote and Danielle Joyal (eds.), Clermont-Ferrand, Adosa.

Flores, Jores (2007): «Distant Wonders. The Strange and the Marvelous Between Mughal India and Habsburg Iberia in the Early Seventeenth Century», Comparative Studies in Society and History, 49, 3, pp. 553-581. DOI: https://doi.org/10.1017/ S001041750700062X

Fougeroux de Bondaroy, Auguste-Denis (1769): «Mémorie sur des insectes sur lesquels on trouve des plantes», Mémoires de l'Académie royale des Sciences, pp. 467-476.

Fougeroux de Bondaroy, Auguste-Denis (1772): «Sur des insectes sur lesquels on trouve des plantes», Histoire de l'Académie Royale des Sciences, pp. 1-5.

Frey, Otto-Herman (2011): «The World of Situla Art», in The Barbarians of Ancient Europe. Realities and Interactions, Larissa Bonfante (ed.), Cambridge, Cambridge University Press, pp. 282-312.

Ganz, David (2010): «Weder eins noch zwei Jan van Eycks Madonna in der Kirche und die Scharnierlogik spätmittelalterlicher Diptychen», in Das Bild im Plural. Mehrteilige Bildformen zwischen Mittelalter und Gegenwart, David Ganz and Felix Thürlemann (eds.), Berlin, Reimer, pp. 41-65.

Garvin, Wilhelma C. (1923): The Development of the Comic Figure in the German Drama from the Reformation to the Thirty years War, Philadelphia, Westbrook Publishing.

GeISSLER, Heinrich (1986-1987): «Ad vivum pinxit. Überlegungen zu Tierdarstellungen der zweiten Hälfte des 16. Jahrhunderts», Jahrbuch der Kunsthistorischen Sammlungen in Wien, 82-83, pp. 101-114.

Giannini, Alexander (ed.) (1966): Paradoxographorum Graecorum reliquiae, Milano, Istituto Editoriale Italiano.

Giménez, Manuel F. (1960): Bartolomé de las Casas. Capellán de S.M. Carlos I Poblador de Cumaná (1517-1523), II, Sevilla, Escuela de Estudios Hispano-Americanos.

Goerge, Rudolf (1993): «Jägerlatein», in Enzyklopädie des Märchens. Handwörterbuch zur historischen und vergleichenden Erzählforschung, Rolf Wilhelm von Brednich (ed.), VII, Berlin / New York, De Gruyter, cols. 420-427.

Goldberg, Christine (1997): The Tale of the Three Oranges, Helsinki, Academia Scientiarum Fennica.

Goodyear, William H. (1891): The Grammar of the Lotus..., London, Sampson.

Gougaud, Louis (1915): «Recherches sur une légende mariale du Moyen Age», in Quatrième congrès marial breton, Quimper, Arsène de Kerangal, pp. 469-476.

Graffius, Peregrine M. (1961): "The "Corona glorious virginis Marie". An Historical Study with Some Doctrinal Conclusions Concerning Our Lady's Crown of Five Psalmus», Studi Storici dell'Ordine dei Servi di Maria, 11, pp. 5-119.

GRISEBACH, Eduard (1880): «Einleitung», in Wunderbare Reisen zu Wasser und Lande..., Stuttgart, Union Deutsche Verlagsgesellschaft, pp. VII-LXII.

Hariot, Paul (1906): «La mousse des cranes», Le Naturaliste, 461, pp. 113-114.

HARSDÖRFFER, Philipp G. (1660): Der grosse Schau-Platz Lust- und Lehrreicher Geschichte..., I, Hamburg, Naumann.

Hartenfels, Georg Christoph Petri Von (1715): Elephantographia curiosa..., Erfurt, J. H. Groschii.

Hernández, V. María del Carmen (2002): El cuento español en los siglos de oro. Siglo $X V I$, I, Murcia, Universidad de Murcia. 
Heyworth, Gregory (2009): «Ineloquent Ends, Simplicitas, Proctolalia, and the Profane Vernacular in the Miller's Tale», Speculum, 84, 4, pp. 956-983. DOI: https://doi. org/10.1017/S0038713400208154

Hirai, Hiro (2011): Medical Humanism and Natural Philosophy. Renaissance Debates on Matter, Life and Soul, Leiden, Brill. DOI: https://doi.org/10.1163/97890042 18727

Holland, Wilhelm L. (ed.) (1855): Die Schauspiele des Herzogs Heinrich Julius von Braunschweig, nach alten Drucken und Handschriften, Stuttgart, Litterarischer Verein.

Hunter, Jerry (1992): «Traddodiad y Celwydd Golau, The Welsh Tall Tale Tradition», Proceedings of the Harvard Celtic Colloquium, 12, pp. 51-62.

Hutchinson, P. (1864): «Baron Munchausen», Notes and Queries, 127, 4 June, p. 468. DOI: https://doi.org/10.1093/nq/s3-V.127.468a

IANNEllo, Fausto (2013): Jasconius rivelato. Studio comparativo del simbolismo religioso dell'"isola-balena" nella Navigatio sancti Brendani, Alessandria, Edizioni dell'Orso.

IkeDA, Hiroko (ed.) (1971): A Type and Motif Index of Japanese Folk-Literature, Helsinki, Academia Scientiarum Fennica.

Jalobeanu, Dana (2018): «Spirits Coming Alive, The Subtle Alchemy of Francis Bacon's Sylva Sylvarum», Early Science and Medicine, 23, 5-6, pp. 459-486. DOI: https:// doi.org/10.1163/15733823-02356P04

Kaufmann, Thomas DaCosta (1988): The School of Prague. Painting at the Court of Rudolf II, Chicago, University of Chicago Press.

KIrCher, Athanasius (1664): Mundi subterranei tomus I..., Amsterdam, Joannem Janssonium et Elizeum Weyerstraten.

KIRCHER, Athanasius (1667): China monumentis qua sacris qua profanis illustrat..., Amsterdam, Jacobum à Meurs.

Kircher, Athanasius (1670): La Chine illustrée..., François Savinien d'Alquié (ed.), Amsterdam, Jansson à Waesberge.

KIrCHER, Athanasius (1987): China Illustrata, with Sacred and Secular Monuments, Various Spectacles of Nature and Art and Other Memorabilia, Charles D. Van Tuyl (ed.), Bloomington, Indiana University Research Institute for Inner Asian Studies.

KIRCHER, Athanasius (2015): Le meraviglie della Cina, Biagio Santorelli (ed.), Bologna, Bononia University Press.

Kummen, Hermann A. (1672): «De ossiculo pruni germinante a rustico excreto», Miscellanea Curiosa; sive, Ephemeridum Medico-Physicarum Germanicarum, 3, pp. 178-180.

Lange, Peter J. (1665): Deliciarum academicarum..., III, Heilbronnae, Leonardum Francum.

Latham, Roy and Schlauch, Frederick C. (1969): «Inscribed Eastern Box Turtles», International Turtle and Tortoise Society Journal, 3, 4, p. 13.

Laurentin, René, and SBalchiero, Patrick (eds.) (2007): Dictionnaire des "apparitions" de la Vierge Marie. Inventaire des origines à nos jours, méthodologie, bilan interdisciplinaire, prospective, Paris, Fayard.

Lavezzo, Kathy (2016): The Accommodated Jew: English Antisemitism from Bede to Milton, Ithaca / London: Cornell University Press. DOI: https://doi.org/10. $7591 / 9781501706158$ 
LeCLerc, Georges-Louis (1785): Natural History, General and Particular..., IV, William Smellie (ed.), London, Strahan and Cadell.

LELLI, Emanuele (2014): Folklore antico e moderno. Una proposta di ricerca sulla cultura popolare greca e romana, Pisa / Roma, Fabrizio Serra.

Libavius, Andreas (1601): Singularium. Pars quarta etultima..., Francofurti, Ioannis Saurii.

LiceTI, Fortunio (1618): De spontaneo viventium ortu..., Venetiis, Bolzetam.

LicETI, Fortunio (1621): De lucernis antiquorum..., Venice, Deuchino.

LiceTI, Fortunio (1640): De quaesitis per epistolas claris viris responsa Fortunii Liceti..., Bononiae, Nicolai Tebaldini.

Long, Eleanor (1980): "“Young Man, I Think You're Dyin". The Twining Branches Theme in the Tristan Legend and in English Tradition», Fabula, 21, 3-4, pp. 184199. DOI: https://doi.org/10.1515/fabl.1980.21.1.183

Loomis, Grant C. (1945): «The American Tall Tale and the Miraculous», California Folklore Quarterly, 4, 2, pp. 109-128. DOI: https://doi.org/10.2307/1495674

Louis, Pierre (1967): «Les animaux fabuleux chez Aristote», Revue des Études Grecques, 80, pp. 242-246. DOI: https://doi.org/10.3406/reg.1967.3945

Lu, Di (2017): Transnational Travels of the Caterpillar Fungus, 1700-1949, PhD dissertation, University College London.

Madison, James (1975): The Papers of James Madison. 9 April 1786-24 May 1787 and supplement 1781-1784, IX, Robert A. Rutland and William M. E. Rachal (eds.), Chicago, University of Chicago Press.

MaÑERo Lozano, David (2020): "A una flor nacida en una calavera, en torno al concepto de propagación contextual», Forthcoming.

MarzolPh, Ulrich (2019): «Ceci n'est point une fable. Tale Type ATU 63, The Fox Rids Himself of Fleas, from Popular Tradition to Natural History (and Back Again)», in Contexts of Folklore Festschrift for Dan Ben-Amos on His Eighty-Fifth Birthday, Simon J. Bronner and Wolfgang Mieder (eds.), New York, Peter Lang, pp. 193-204.

Maxwell-Stuart, Peter G. (1971): «Dionysus and the Fawnskin», The Classical Quarterly, 21, 2, pp. 437-439. DOI: https://doi.org/10.1017/S0009838800033589

MaYer, Hagin F. ed. (1986): The Yanagita Kunio Guide to the Japanese Folk Tale, Bloomington, IN, Indiana University Press.

McMullen, Bradford M. (2015): An Examination of the Celwydd Golau, MPhil thesis, Cardiff University.

Michelet, Mialaret A. (1872): Nature, or the Poetry of Earth and Sea, London, T. Nelson.

Mгуоко, Sasaki and Heinz, Morioka (1981): «Rakugo, Popular Narrative Art of The Grotesque», Harvard Journal of Asiatic Studies, 41, 2, pp. 417-459. DOI: https:// doi.org/10.2307/2719050

Мгуоко, Sasaki and Heinz, Morioka (1990): Rakugo. The Popular Narrative Art of Japan, Cambridge, MA, Council on East Asian Studies, Harvard University.

Molina, Michelle J. (2004): «True Lies, Athanasius Kircher's China Illustrata and the Life Story of a Mexican Mystic», in Athanasius Kircher. The Last Man Who Knew Everything, Paula Findlen (ed.), New York / London, Routledge, pp. 365-383.

Moser, Dietz-Rüdiger (1977): «Ave Maria auf Lilien», in Enzyklopädie des Märchens. Handwörterbuch zur historischen und vergleichenden Erzählforschung, Rolf Wilhelm von Brednich (ed.), I, Berlin / New York, De Gruyter, cols. 1095-1097.

MÜLLER (1790): «Hirsch», in Deutsche Encyclopädie oder Allgemeines Real-Wörterbuch aller Künste und Wissenschaften. Heil-Holz, XV, Frankfurt, Varrentrapp und Wenner, pp. 579-602. 
MüLlER, Michael (1988): «Un libro in cerca d'autore», in Erich R. Raspe, Le avventure del barone di Münchhausen, Michael Müller (ed.), Pordenone, Studio Tesi, pp. IX-XXVII.

MüLLER-Fraureuth, Carl (1881): Die deutschen Lügendichtungen bis auf Münchhausen, Halle, Max Niemeyer.

Muramatsu, Masumi (1988): «Japanese Art Patrons, Ikenaga Hajime Inventor of an Era Sekmizu», Look Japan, 34, pp. 35-36.

Nieremberg, Juan Eusebio (1635): Historia naturae, maxime peregrinae..., Amberes, Baltasar Moreto.

ODA, Shōkichi (1989): «Rakugo Recycled», Look Japan, 34, pp. 47-48.

Oldenburg, Henry (1667): «Review of China monumentis qua sacris qua profanis, by Athanasius Kircher», Philosophical Transactions..., 2, pp. 484-488.

Olmi, Giuseppe and Simoni, Fulvio (eds.) (2018): Ulisse Aldrovandi. Libri e immagini di storia naturale nella prima età moderna, Bologna, Bononia University Press.

PAullini, Christian Franz (ed.) (1686): «Breviarium rerum memorabilium...», Miscellanea Curiosa; sive, Ephemeridum Medico-Physicarum Germanicarum, 4, pp. 177-216.

Pfeiffer, Franz (1849): «Die Tragödien und Comödien des Herzog Heinrich Julius von Braunschweig», Serapeum, 12, pp. 185-190.

Pimentel, Juan (2009): «Baroque Natures, Juan E. Nieremberg, American Wonders, and Preterimperial Natural History», in Science in the Spanish and Portuguese Empires, 1500-1800, Daniela Bleichmar, Paula De Vos, Kristin Huffine and Kevin Sheehan (eds.), Stanford, CA, Stanford University Press, pp. 94-114. DOI: https:// doi.org/10.2307/j.ctvqr1dp8.13

Pliny (1830): Histoire naturelle, V, Ajasson de Grandsagne (ed.), Paris, Panckoucke.

Pliny (1940): Natural History, Volume III, Books 8-11, Harris Rackham (ed.), Cambridge, MA, Harvard University Press.

Pliny (1976): Naturalis historia. Zoologie, Landtiere, VIII, Roderich König and Gerhard Winkler (eds.), Kempten, Heimeran Verlag.

Plumley, Ladd (1921): «Watery Long Life», Boy’s Life, October, p. 36.

Preus, Anthony (1975): Science and Philosophy in Aristotle's Biological Works, Hildesheim, Olms.

Propp, Vladimir Y. (1975): «L'albero magico sulla tomba. A proposito dell'origine della fiaba di magia», in Id., Edipo alla luce del folklore, Torino, Einaudi, pp. 3-40.

Provençal, Philippe (2010): The Arabic Plant Names of Peter Forsskål's Flora AegyptiacoArabica, Copenhagen, The Royal Danish Academy of Sciences and Letters.

Pseudo-Antigonus of CARystos (1986): Rerum mirabilium collectio, Olimpio Musso (ed.), Napoli, Bibliopolis.

Pseudo-Antigonus of Carystos (2014): Antigonus 26-30. Unpublished translation by Rachel Hardiman. URL: <http://paradoxography.blogspot.com/2014/09/>.

Raspe, Erich R. (1895): The Surprising Adventures of Baron Munchausen, London, Lawrence and Bullen.

RASPe, Erich R. (1948): Singular Travels, Campaigns and Adventures of Baron Munchausen, John Carswell (ed.), London, The Cresset Press.

Regnault, Noël (1732): Les entretiens physiques d'Ariste et d'Eudoxe..., III, Paris, Clouzier.

Rоотн, Birgitta A. (1992): Exploring the Garden of Delights. Essays in Bosch's Paintings and the Medieval Mental Culture, Helsinki, Suomalainen Tiedeakatemia, Academia Scientiarum Fennica. 
Rose, William (1931): Men, Myths, and Movements in German Literature, London, George Allen \& Unwin.

Salazar y Castro, Luis de (1694): Historia genealógica de la Casa de Lara, Madrid, Llanos y Guzman.

SALES, Mònica (2002): La rondalla en les revistes publicades a Catalunya durant el segle $X I X, \mathrm{PhD}$ dissertation, Universitat Rovira i Virgili.

SAnz, Carlos G. (2013): «Las formas breves de la narrativa folklórica en la comarca de Valdejalón (Zaragoza)», Estudis de Literatura Oral Popular, 2, pp. 97-113. DOI: https://doi.org/10.17345/elop201397-113

Scaligero, Giulio Cesare (1566): Commentarii et Animadversiones in sex libros De causis plantarum Theophrasti..., Geneva, Crispinum.

Scarborough, John (2002): «Herbs of the Field and Herbs of the Garden in Byzantine Medicinal Pharmacy», in Byzantine Garden Culture, Antony Littlewood, Henry Maguire and Joachim Wolschke-Bulmahn (eds.), Washington D.C., Dumbarton Oaks, pp. 177-188.

SCHACHENMAYR, Alkuin Volker (2013): «Chrysostomus Hanthalers Lilienfelder Fälschungen als hermeneutische Grenzgänge», Studien und Mitteilungen zur Geschichte des Benediktinerordens und seiner Zweige, 124, pp. 261-287.

SCHENDA, Rudolf(1958): «Philippe le Picard und seine Nouvelle Fabrique. Eine Studie zur französischen Wunderliteratur des 16. Jahrhunderts», Zeitschrift für Französische Sprache und Literatur, 68, 1-2, pp. 43-61.

Scheuchzer, Johann Jakob (1735): Physique sacrée, ou histoire-naturelle de la Bible, VI, Amsterdam, Schenk \& Mortier.

Schnieders, Stefan (2013): «Fabulöses und Mirabilien bei Aristoteles, besonders in Historia animalium IX», Antike Naturwissenschaft und Ihre Rezeption, 23, pp. 11-30.

SchuRIG, Martin (1725): Chylologia historico-medica..., Dresdae, Zimmermanni \& Gerlachii.

Seccombe, Thomas (1895): «Introduction», in Erich R. Raspe, The Surprising Adventures of Baron Munchausen, London, Lawrence and Bullen, pp. V-XXXVIII.

SEKI, Keigo (1966): «Types of Japanese Folktales», Asian Folklore Studies, 25, pp. 1-220. DOI: https://doi.org/10.2307/1177478

Sennert, Daniel (1636): Hypomnemata Physica..., Frankfurt, Clement Schleich.

SHARPLES, Robert W. (1995): Theophrastus of Eresus. Sources for his Life, Writings, Thought and Influence. Commentary. Sources on Biology, Human Physiology, Living Creatures, Botany, Texts 328-435, V, Brill, Leiden. DOI: https://doi. org/10.1163/9789004320864

SHore, Teignmouth, T. (1867): «Introduction», in Erich R. Raspe, The Adventures of Baron Munchausen, London, Cassell, Petter and Galpin, pp. XIII-XV. DOI: https://doi. org/10.5479/sil.468008.39088007755572

Sigaud DE LA Fond, Joseph-Aignan (1781): Dictionnaire des merveilles de la nature, II, Paris, Rue et Hotel Serpente.

Southey, Robert (1808): «Omniana», The Athenaeum, 21, pp. 222-225.

Stalpart van der Wiel, Cornelius (1758): Observations rares de médecine..., II, Paris, L.-C. d'Houry.

Stensen, Niels (1997): Chaos, Niels Stensen's Chaos-Manuscript Copenhagen, 1659, August Ziggelaar (ed.), Copenhagen, The Danish National Library of Science and Medicine. 
Stetkevych, Jaroslav (2002): «In Search of the Unicorn. The Onager and the Oryx in the Arabic Ode», Journal of Arabic Literature, 33, 2, pp. 79-130. DOI: https://doi. org/10.1163/157006402320379371

TÁvora, Mascarenhas de J. T., and da Costa, José V. (eds.) (1730): «Lisboa oriental. Caz de Santarem 2 de Outubro», Folheto de Ambas Lisboas, 7, p. 3.

Theophrastus (1976): De Causis Plantarum, Vol. 1, Books 1-2, Benedict Einarson and George K. K. Link (eds.), Cambridge, MA, Loeb Classical Library. DOI: https:// doi.org/10.4159/DLCL.theophrastus-de_causis_plantarum.1976

Thesaurus Exemplorum Medi Aevi (2017): ThEMA: Thesaurus Exemplorum Medii Aevi. URL: <http://thema.huma-num.fr/>.

Thomas, Gerald (1977): The Tall Tale and Philippe D'Alcripe. An Analysis of the Tall Tale Genre with Particular Reference to Philippe D'Alcripe's La nouvelle fabrique des excellents traits de vérité, Together with an Annotated Translation of the Work, St. John's, Department of Folklore, Memorial University of Newfoundland,

Thomas, Gerald (1999): «Münchhausiaden», in Enzyklopädie des Märchens. Handwörterbuch zur historischen und vergleichenden Erzählforschung, Rolf Wilhelm von Brednich (ed.), IX, Berlin / New York, De Gruyter, cols. 1008-1015.

Thompson, Stith (ed.) (1955-1958), Motif-Index of Folk-Literature. A Classification of Narrative Elements in Folktales, Ballads, Myths, Fables, Medieval Romances, Exempla, Fabliaux, Jest-books, and Local Legends, 6 vols., Bloomington, Indiana University Press.

Tubach, Frederic C. (ed.) (1969): Index Exemplorum. A Handbook of Medieval Religious Tales, Helsinki, Suomalainen Tiedeakatemia, Academia Scientiarum Fennica.

Ujvári, Péter (1993): «Painting Animals», in The Metamorphosis of Themes. Secular Subjects in the Baroque Art of Central-Europe, Miklós Mojzer (ed.), Budapest, Szépmüvészeti Múzeum, pp. 92-113.

UtHer, Hans-Jörg (ed.) (2011): The Types of International Folktales. A Classification and Bibliography Based on the System of Antti Aarne and Stith Thompson. Animal Tales, Tales of Magic, Religious Tales, and Realistic Tales, with an Introduction, I, Helsinki, Suomalainen Tiedeakatemia, Academia Scientiarum Fennica.

Uther, Hans-Jörg (ed.) (2015): Deutscher Märchenkatalog. Ein Typenverzeichnis, Münster / New York, Waxmann Verlag.

VAllisneri, Antonio (1721): «Prima lettera. Disamina d'un solo articolo dell'opera celebre della generazione de' vermi del corpo umano del sig. Andry...», in Id., De' corpi marini..., Venezia, Domenica Lovisa, pp. 144-176.

Voigt, Gottfried (1668): Curiositates physicae..., Gustrow, Sceippelius.

Wallnig, Thomas and Stockinger, Thomas (eds.) (2010): Die gelehrte Korrespondenz der Brüder Pez. Text, Regesten, Kommentare. 1709-1715, I, Wien, Böhlau. DOI: https://doi.org/10.26530/OAPEN_445402

Waltmann, Johann Paul (1729): Der Lustige Teutsche..., Nürnberg, Johann Andreas Seitz.

Walton, David A. (1966): «Pennsylvania Riverboat Stories», Keystone Folklore Quarterly, 11, 4, pp. 215-238.

WeisING, Christina (2008): "A Vision of "Sexuality" or "Nudity". Regional Differences in the Images of Corbels», in Sexuality in the Middle Ages and Early Modern Times, Albercht Classen (ed.), Berlin / New York, Walter de Gruyter, pp. 325-382. DOI: https://doi.org/10.1515/9783110209402.325

WiLliam, Malm P. (1998-1999): «Yamada Shôtarô, Japan's First Shamisen Professor», Asian Music, 30, 1, pp. 35-76. 
ZAHN, Johann (1696): Specula physico-mathematico-historicaa..., Nurenberg, Lochner. Ziegler, Joseph (1998): Medicine and Religion c. 1300. The Case of Arnau de Vilanova, Oxford, Clarendon. DOI: https://doi.org/10.2307/834263

Ziolkowski, Jan M. (2007): Fairy Tales from Before Fairy Tales, The Medieval Latin Past of Wonderful Lies, Ann Arbor, University of Michigan Press. DOI: https://doi. org/10.3998/mpub.105158

ZúÑIGa, Don Francés de (1981): Crónica burlesca del emperador Carlos V, Diane Pamp de Valle-Arce (ed.), Barcelona, Crítica.

ZúÑIgA, Don Francés de (1989): Crónica burlesca del emperador Carlos V, José Antonio Sánchez Paso (ed.), Salamanca, Universidad de Salamanca.

Fecha de recepción: 22 de diciembre de 2019

Fecha de aceptación: 11 de junio de 2020

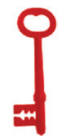

